\title{
ESPELHOS ERÓTICOS. ERÓTICA NO ESPELHO. UMA ICONOGRAFIA AMOROSA DA HÉLADE (SÉC. V-IV A.C.)
}

Fábio Vergara Cerqueira1

\section{Resumo}

O presente texto consiste em um ensaio interpretativo sobre o(s) sentido(s) do objeto espelho na Grécia egeia (em contraste à Grécia ocidental/colonial), com base na iconografia, levando em consideração dois repertórios imagéticos distintos: a pintura dos vasos áticos (final do sexto a início do quarto século) e a decoração figurada dos espelhos em si, em relevo e gravada por incisão (final do quinto a início do terceiro século). O foco central de análise é a iconografia registrada nos espelhos produzidos nos quatro principais centros da indústria grega de espelhos (Atenas, Corinto, Cálcis, Jônia). Dentre os três tipos de espelho produzidos, quais sejam, espelho de mão, espelho de mesa e espelho de caixa, é fundamentalmente o terceiro tipo que contribui para este estudo. Os espelhos de caixa podem portar iconografia em sua cobertura dobrável, em relevo na superfície externa e gravada por incisão na superfície interna. Em contraste com a iconografia de vasos da Magna Grécia, em que o componente místico se sobressai entre vários simbolismos, no caso da iconografia do/no espelho produzida na Grécia egeia prevalece o simbolismo erótico e a ligação com Afrodite, por meio de cuja proteção se acolhem todas as categorias de mulheres (hetairas, "mulheres-cidadãs" casadas ou noivas) e todos as modalidades de amores - o poder simbólico do espelho estaria relacionado a um erótica inclusiva, que une sob a égide do amor e desejo aquilo que a sociedade separa.

\section{Palavras-chave}

Espelho; cultura material; iconografia; cerâmica; erótica; Afrodite.

\footnotetext{
1 Professor Titular, Universidade Federal de Pelotas, Pelotas, Brasil. E-mail: fabiovergara@uol.com.br
} 


\begin{abstract}
This text consists of an interpretive essay about the meaning(s) of the "mirror" as an object in Mainland and Aegean Greece (in contrast to Western/Colonial Greece), based on iconography. I take into consideration two distinct repertoires of images: the paintings of Attic vases (late sixth - early fourth century B.C.) and the figurative decoration on the mirrors themselves, in relief or engraved (late fifth - early third century B.C.). The central focus of the analysis is the iconography registered on mirrors produced in the four main manufacturing centers of Greece (Athens, Corinth, Chalcis, Ionia). Greeks produced three types of mirrors between Late Archaic and Early Hellenistic times: hand-mirrors with handle, table mirrors with stand, and round box mirrors, the latter being the most important to this study. Box mirrors may bear iconography on their folding cover, in relief on the external surface (repoussé) or engraved on the interior surface. In contrast to the iconography of the vases of Magna Graecia, in which the mystic component stands out from the other symbolic aspects, in the case of the iconography of Greek mirrors erotic symbolism and the relation with the goddess Aphrodite predominate. This goddess protects all categories of women (hetaerae and "citizen-women", married or brides) and all modalities of eroticism. Under the auspices of love and desire, the symbolic power of the mirror can be related to an inclusive eroticism, which unites, that which society separates.
\end{abstract}

\title{
Key words
}

Mirror; material culture; iconography; pottery; eroticism; Aphrodite. 
Imagens de espelho e imagens no espelho: sentidos de um objeto

A torêutica grega teve como um de seus produtos de maior destaque a produção de espelhos, portadores de requinte ornamental que se expressa desde o final do século VI, por exemplo com a produção de espelhos com pegadores ou suportes em forma de cariátides (Fig. 1). Trata-se de um objeto presente ao mesmo tempo no registro material, sobretudo funerário, e no registro iconográfico, nomeadamente na pintura de vasos. Os possíveis sentidos associados a este objeto, para além de seus usos pragmáticos, instiga nossa compreensão, afinal, "desde tempos remotos, o espelho exerceu fascínio sobre o espírito humano" (Kuzmina 2013: 156).

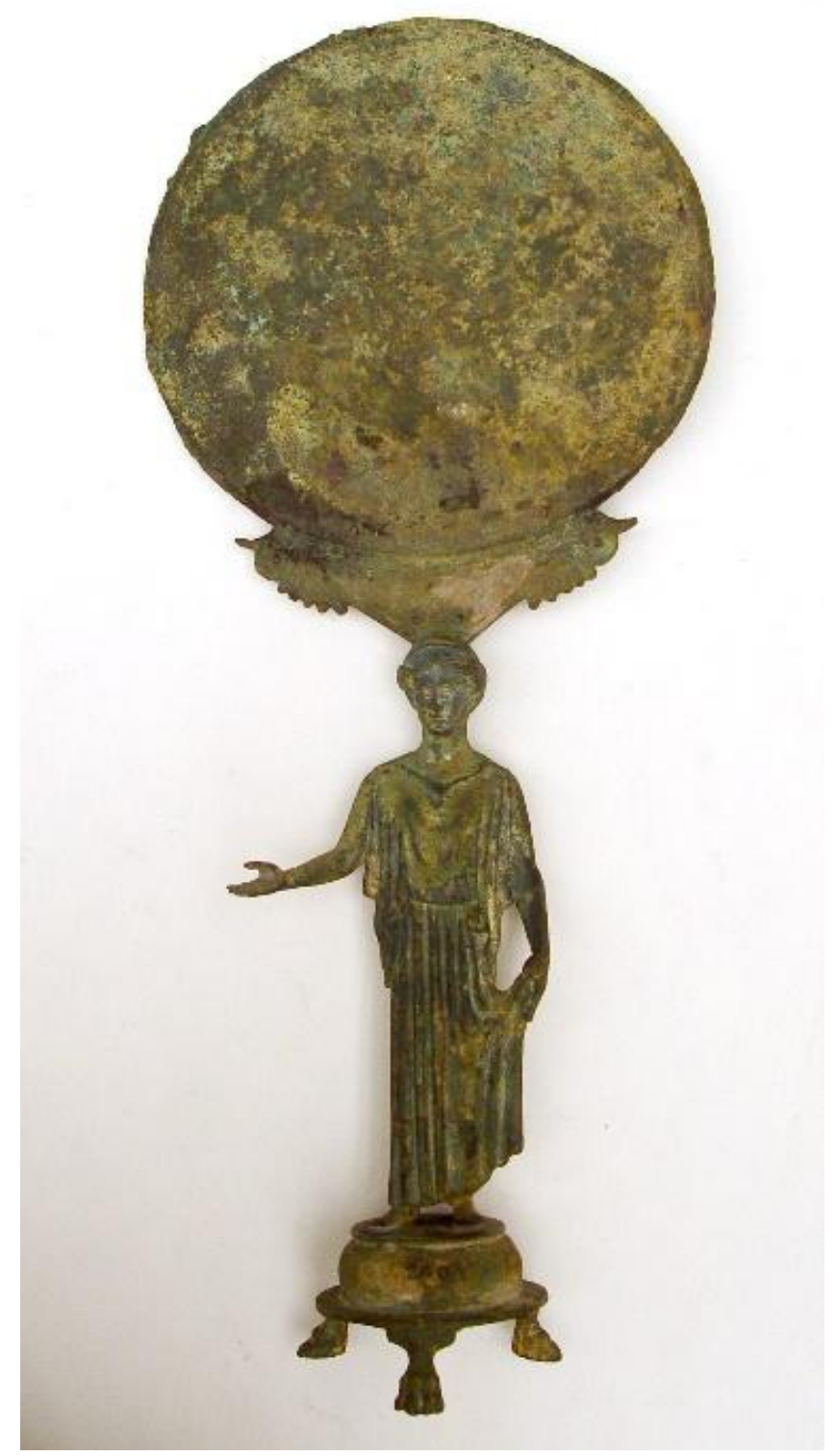

Fig. 1. Espelho de mesa com suporte em cariátide: Originalmente a figura feminina tinha uma pomba na mão direita. Londres, Museu Britânico, inv. 1873,0820.235. Produção: Argos. Proveniência: Atenas. c. 460 a.C. (OTrustees of the British Museum 
$\mathrm{Na}$ Grécia egeia ${ }^{2}$, quatro centros se destacaram na produção de espelhos, entre finais do período arcaico e inícios do helenístico: Cálcis, Atenas, Corinto e Jônia. A indústria de espelhos se expandiu para a península itálica, onde, entre o tardo-clássico e o proto-helenístico, se desenvolveu uma importante produção, tanto na Etrúria quanto na Magna Grécia, na qual se destacaram Tarento e Locri-Epizefiri como importantes centros produtores (Treister 1996: 207-209). Uma singularidade destes espelhos é o requinte estético e comunicativo de serem portadores de imagens figuradas, como apliques de pegadores ou suportes, ou como cena registrada em uma das superfícies, em relevo ou gravadas por incisão. Contemporaneamente a esta produção industrial torêutica, o objeto espelho foi alvo da atenção de produções visuais, como referente visual, sendo representado em larga escala na pintura dos vasos áticos.

Nosso interesse, neste estudo, é refletir sobre sentidos atribuídos ao objeto espelho e suas representações na cultura grega antiga, procurando observar, no que se refere ao período entre o final do arcaico e o início do helenístico, o quanto as representações do/no "mundo do espelho" 3 na Grécia egeia guardam singularidades com relação àquelas observadas na Grécia ocidental, em especial na Magna Grécia, posto que os contextos coloniais engendram situações ricamente interculturais de hibridização, que estimulam reformulações ou descontinuidades de sentidos culturais trazidos junto a práticas sociais ou objetos introduzidos por meio dos contatos coloniais. Os estudos feitos sobre o tema têm abordado o espelho na cultura grega de forma genérica, sem considerar as descontinuidades e singularidades culturais existentes entre contextos gregos heládicos e contextos gregos coloniais interculturalizados (Frontisi-Ducroux, Vernant 1997. Hartlaub 1951. Delatte 1932). Nosso foco, neste ensaio, será o contexto da Grécia egeia, como produtor de uma imagem social do espelho própria, posto que já abordamos o contexto da Grécia ocidental, em um estudo sobre o espelho na iconografia dos vasos ápulos (Vergara Cerqueira, 2018 prelo).

Segundo Eugenia Kuzmina (2013: 157), “a consciência humana concedeu aos espelhos os valores estéticos, axiológicos e gnoseológicos que, por sua vez, determinaram os papeis multifuncionais e polissêmicos do objeto na cultura". Conforme a autora, o significado estético se relacionaria às

2 Entendemos aqui por Grécia egeia o conjunto formado pela Grécia continental balcânica, pela Grécia insular egeia e pela porção grega da Ásia Menor, sobretudo a Jônia, em oposição à Grécia ocidental, neste estudo indicada precipuamente em referência à Magna Grécia.

${ }^{3}$ Expressão crivada por Françoise Frontisi-Ducroux para dar conta do mundo que se cria em torno do espelho (Frontisi-Ducroux, Vernant 1997: 51-133). 
"qualidades técnicas" do objeto, a função axiológica, à "capacidade do objeto atuar como indicador de juízos de valores", e o aspecto gnosiológico, a poder "servir como meio de aprendizagem e autoconhecimento". Diante de tais possibilidades interpretativas, propomos aqui refletir sobre a potencialidade - e necessidade - de uma interpretação de sentidos do espelho sustentada em evidências iconográficas - no caso, evidências de dois tipos: imagens representadas sobre superfícies dos próprios espelhos e imagens de espelhos como parte das cenas pintadas sobre vasos. Entendemos que este repertório visual guarda, de forma entrelaçada, aspectos dos valores estéticos e axiológicos referidos acima, de sorte que as imagens do e no espelho expressam - e, mais que isso, configuram - simbolismos que estruturam o estatuto social e cultural do espelho.

Contudo, para se compreender a particular significação do espelho na Grécia egeia, é preciso se levar em conta aquilo que é próprio à cultura material em análise (o suporte material destas cenas, logo, o objeto "espelho" em si, e a coisa representada, logo, o referente visual "espelho"):

O espelho em sua dimensão material forma parte do processo histórico e seu destino é inseparável do contexto da cultura. Caracteriza-se também pelo dinamismo, na medida em que sua orientação conceitual e perspectiva se enriquece em cada era, com novas implicações semânticas. Em cada época, o homem definiu sua visão do objeto, lhe assinalou certos valores e funções, reconsiderou seu estatuto. Como resultado disto, cada época configurou uma imagem determinada do espelho (Kuzmina, 2013: 158).

Buscamos então compreender o estatuto do espelho, por meio do qual se configura uma imagem social sua, com base em uma Arqueologia da Imagem, levando-se "em conta os vários tipos de objetos que serviram de suportes dessas imagens ou que eram eles próprios imagens" (Sarian, 1999: 70). É assim que nossa reflexão se ancora no diálogo entre as imagens pintadas sobre vasos e as imagens registradas sobre espelhos.

Cabe lembrar que uma coisa é o espelho objeto (referente), com seus fins práticos primeiros ligados aos cuidados da beleza e vaidade pessoal feminina (Vernant, 1989: 118; Kuzmina, 2013: 158), e outra coisa é a representação gráfica do espelho, o signo visual espelho, composto pelo significante, que é o desenho e pintura que o retrata na pintura dos vasos, e pelos significados vinculados, que podem ser significados da ordem pragmática ou da ordem simbólica de uso destes objetos. Vale ressaltar também que a dimensão pragmática de um objeto como o espelho não se limita necessariamente a sua função inicial de reflexo do rosto na toalete, função essencialmente feminina (Vernant, 1989: 118), pois pode 
incorporar outros usos, como por exemplo usos religiosos - e.g. culto a Eros (Schneider-Herrmann, 1970) - usos que podem acrescentar, à dimensão simbólica do espelho, além de aspectos de gênero (vinculação feminina), elementos da mística (Hartlaub, 1951. Delatte, 1932), de modo a mesclar assim aspectos eróticos com aspectos funerários ou oraculares (vale lembrar que, nestes outros usos, a exclusividade feminina cede lugar, podendo ser usado também por homens) (Cassimatis, 1998: 297301).

A iconografia da cerâmica ápula do séc. IV é testemunho de o quanto, na Magna Grécia, a simbologia impregnada na representação visual do espelho incorpora outras significações relevantes, para além dos cuidados estéticos pessoais: dimensões místicas, religiosas, funerárias e oraculares ganham destaque (Vergara Cerqueira, 2018) - aspectos pouco presentes na iconografia do espelho na pintura dos vasos áticos. A constatação deste contraste relativo à representação do espelho, verificado na comparação entre a pintura dos vasos áticos e ápulos, incita-nos a compreender a especificidade do campo simbólico predominante na apropriação cultural do objeto espelho na Grécia egeia, onde se concentraram algumas importantes indústrias de espelho.

Nesse sentido, Lilian Balensiefen (1990: 28) aduz que, na Grécia antiga, o espelho, "como aparelho cosmético, açambarca a esfera de vida da mulher e funciona como símbolo de sua beleza e juventude", o que mistura dimensão prática e simbólica. Segundo esta autora, o contexto iconográfico de representação do espelho, na arte grega, é marcado mais frequentemente por cenas da vida diária, do domínio do gineceu e da toalete feminina, que podem estar inseridas também em um contexto sepulcral". Penso que, no caso da iconografia da cerâmica ática ou dos espelhos coríntios, deva-se acrescentar o domínio do hetairaion, também feminino, mas com outra implicação social. Balensiefen sintetiza colocando que o espelho é tratado genericamente como um utensílio ao qual se acrescenta um caráter de atributo (por via de regra, atributo de gênero, da mulher em geral, mas pode também ser atributo de uma divindade feminina, em particular, Afrodite).

Aspectos pragmáticos e simbólicos se impregnam, de formas variadas, no conjunto de elementos que compõem o objeto espelho. Os pegadores, por exemplo, podem ser simples cabos, mas podem se tornar suporte de ornamentação, a qual pode ou não receber conteúdo iconográfico. $\mathrm{O}$ conteúdo iconográfico da ornamentação de um pegador, comumente ligado a Afrodite e Eros, pode carregar conteúdo simbólico, por exemplo relacionado à erótica. Um traço original dos espelhos de bronze gregos e daqueles produzidos sob a influência de sua tradição, na Magna Grécia e 
Etrúria, é serem portadores de rica iconografia em suas superfícies internas e externas, respectivamente por incisão ou relevo. A presença desta decoração é testemunho não somente do desenvolvimento de manufaturas sofisticadas com mão de obra altamente especializada, mas sobretudo da importância material e simbólica deste objeto na cultura grega, o que reforça a relevância de se buscar decodificar seus conteúdos simbólicos, bastante inteligíveis para os usuários da época, usuários do espelho objeto e do espelho signo visual, mas de difícil compreensão para o intérprete moderno, exigindo um esforço hermenêutico. Tomamos a liberdade de nos apropriarmos aqui do que coloca Hélène Cassimatis (1992: 111; 1998: 298), ao se referir à iconografia dos vasos ápulos: “o objeto mais enigmático segue sendo o espelho", "sua significação permanecendo fugidia".

Neste estudo ensaístico sobre o espelho grego, buscaremos elaborar uma reflexão sobre seu simbolismo cultural, por meio de análise comparada entre a iconografia do espelho e a iconografia no espelho, cotejando, respectivamente, as imagens representadas na cerâmica ática e na torêutica grega, entre finais do século VI e finais do século IV.

Deste modo, inicialmente farei uma breve apresentação do espelho na Antiguidade. Passarei então a um comentário sobre a iconografia do e no espelho na Grécia, abordando a pintura dos vasos áticos e, a seguir, a decoração figurada em espelhos, nomeadamente das quatro principais indústrias gregas da Hélade (Cálcis, Atenas, Corinto e Jônia).

\section{Sobre o objeto espelho na Antiguidade}

O fabrico de espelhos usando folhas de metal polido, inicialmente cobre, depois bronze, começou na Mesopotâmia ainda no quarto milênio antes de Cristo, chegando mais tarde ao Egito. Substituía as soluções anteriores, encontradas pelo homem, como a superfície de água parada, preferencialmente sobre um recipiente, ou pedra polida, como a obsidiana, usada para este fim desde o sexto milênio na Anatólia. Por muitos séculos, predominaram no Mediterrâneo os espelhos de bronze, que refletiam a imagem sobre a superfície polida, levemente côncava ou convexa.

Os vestígios arqueológicos mais recuados do uso do vidro como superfície para a reflexão de imagens nos espelhos na Grécia remonta ao século III, como testemunham alguns exemplares muito pequenos; 
segundo Plínio o Velho (N.H. XXXVI.66) ${ }^{4}$, testemunho mais antigo do fabrico de espelhos de vidro, seu desenvolvimento se deu em Sídon, devido provavelmente aos aperfeiçoamentos locais na técnica do vidro soprado, o que teria ocorrido no primeiro século da era comum (Melchior-Bonnet, 2002: 12. Glyn-Jones, 1996: 136), disseminando-se finalmente ao longo do período antonino.
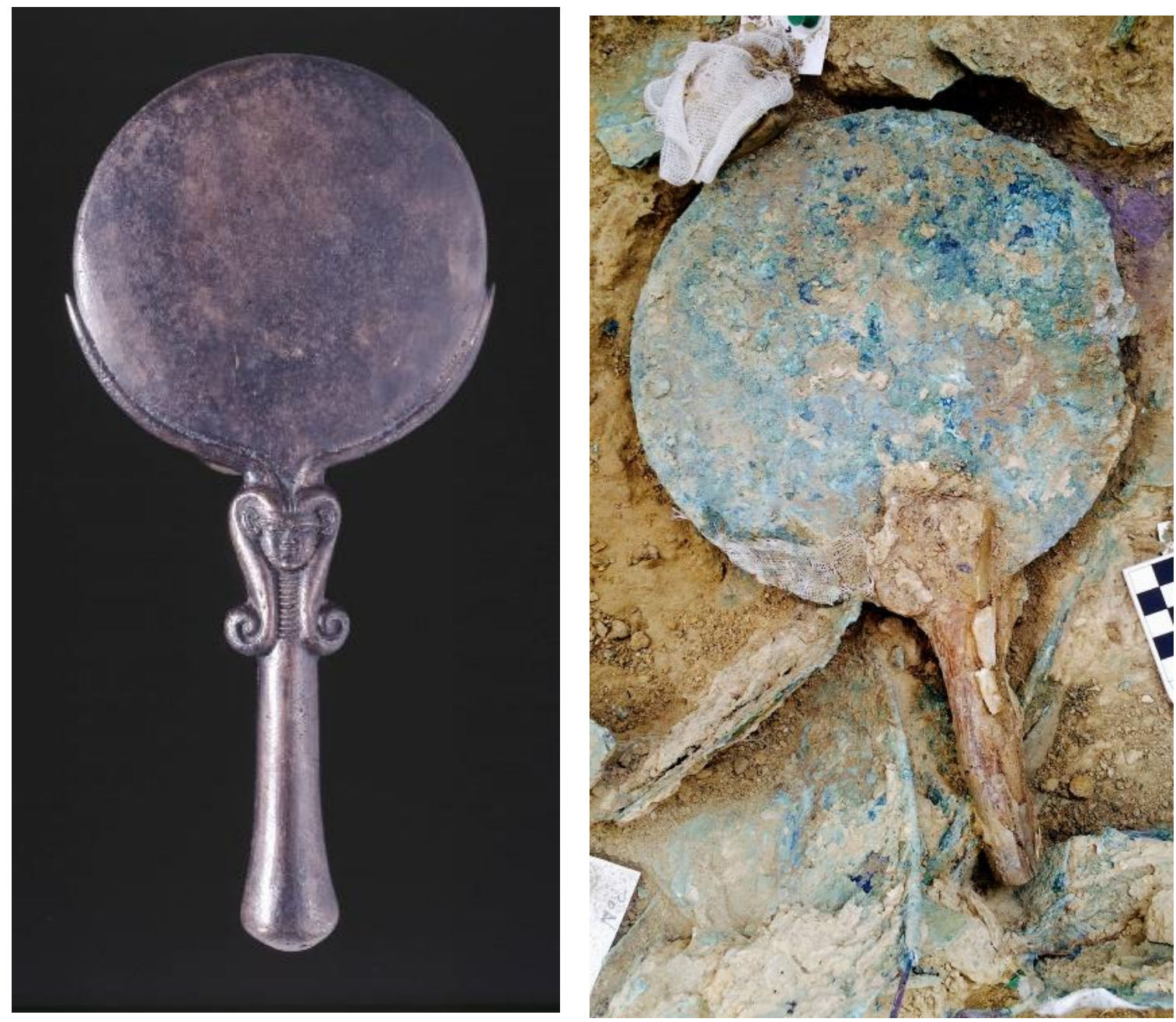

Fig. 2. (esquerda) Espelho de mão egípcio: Bronze. Londres, Museu Britânico, EA29428 (1897.0511.144). Reino Novo. (CTrustees of the British Museum.

Fig. 3. (direita) Espelho de mão. Bronze (disco) e marfim (pegador): Tumba do "Guerreiro do Grifo" ("Griffin Warrior"), Pilos. (c) Foto: Department of Classics/University of Cincinnati

4 "This mass is again subjected to fusion in the furnace, for the purpose of colouring it; after which, the glass is either blown into various forms, turned in a lathe, or engraved like silver. Sidon was formerly famous for its glass-houses, for it was this place that first invented mirrors" (Bostock). (...) ex massis rursus funditur in officinis tinguiturque, et aliud flatu figuratur, aliud torno teritur, aliud argenti modo caelatur, sidone quondam his officinis nobili, siquidem etiam specula excogitaverat (Mayhoff). 
O Egito se destaca quanto ao grande número de espelhos conservados. Estes compunham-se de duas partes: a folha arredondada de bronze com a superfície polida, e o pegador, que poderia ser feito de material diferente e encaixado, sendo o mais usual a madeira. A placa de bronze, arredondada no geral, sofria na base uma alteração em sua forma, para encaixe do cabo. Os pegadores poderiam ter sua extremidade inferior com o formato adaptado para que o espelho pudesse ficar de pé, como se observa em um exemplar conservado no Louvre ${ }^{5}$. Exemplares mais sofisticados poderiam ser feitos de uma peça só, toda de bronze. Neste caso, o pegador poderia ganhar uma elaboração plástica, como é o caso do espelho conservado no Museu Britânico, com a parte superior do cabo em forma de cabeça de Hathor (Fig. 2) ${ }^{6}$, o que, além de reforçar o caráter de luxo, agrega valor simbólico, associando o espelho ao domínio do amor e da festa, do glamour, e à dignidade da deusa-esposa.

No segundo milênio antes da era comum os espelhos são encontrados nas culturas egeias da Bacia Oriental do Mediterrâneo. Um exemplar de bronze com cabo de marfim foi achado recentemente por uma equipe da Universidade de Cincinnati, na tumba de um guerreiro em Pilos, no Peloponeso, datado de aproximadamente 1.500 a.C., indicando que a posse de um objeto desta natureza na sociedade micênica era designadora de uma condição elitária7 (Fig. 3). Os espelhos de mão de tipo argivocoríntio são evidenciados desde o período arcaico, sendo os mais antigos entre os gregos.

No período tardo-arcaico e clássico, os gregos produziram três tipos de espelho: espelho de mão com cabo (pegador), espelho de mesa (com base de sustentação na extremidade inferior do cabo) e espelho de caixa circular com cobertura. Este consistia de dois discos metálicos articulados, um polido na frente, e a tampa (Ridder 1909: 1424; Mattusch 2010: 402) (Fig. 16a-b) ${ }^{8}$. No registro arqueológico, nos séculos V e IV,

\footnotetext{
${ }^{5}$ Espelho de mão egípcio. Placa de bronze, cabo de madeira. Paris, Louvre, 162. c. 1.300 a.C.

6 Apesar de espelhos com cabeça de Hathor estarem entre os mais comuns, costumavam ornamentar a parte superior do cabo também com outras divindades: cabeça de falcão, portanto, do deus Hórus: 1) Museu Britânico, EA32583 e EA2731; Bês: EA37176.

7 Missão arqueológica da Universidade de Cincinnati, campanha de 2015, número de achado 1310. Link: https:/ / www.nytimes.com/2015/10/27/science/a-warriors-graveat-pylos-greece-could-be-a-gateway-to-civilizations.html. Extraído em 19.12.2017.

8 O termo "espelho de caixa" corresponde à tradução da terminologia adotada por exemplo no francês ("miroir à boîte") e no inglês ("box mirror"). Em alemão, no entanto, recebe a denominação de Klappspiegel (espelho dobrável), denominação igualmente adequada, pois se refer ao modo de ser usando, dobrando a cobertura para cima.
} 
predominam os espelhos de mesa ou de caixa com cobertura, ao passo que, na pintura dos vasos áticos, a situação se inverte, prevalecendo amplamente os espelhos de mão, devendo-se, suponho, a os espelhos de mão serem mais facilmente representados em desenhos bidimensionais.

Havia uma denominação geral para espelho, que oscilava entre os termos

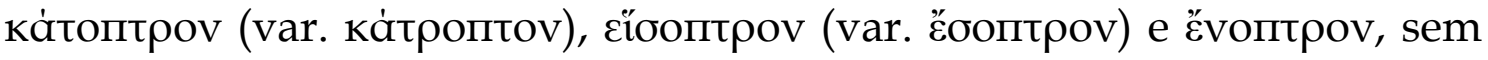
explicitar uma correspondência exata entre vocábulo e tipo de espelho. Alguns, com base em uma passagem de Aristófanes (Nub. 749),

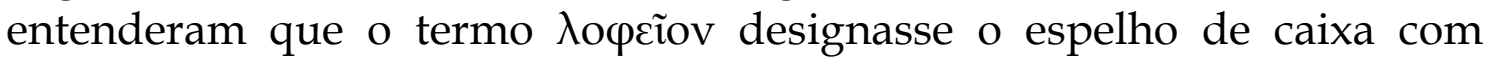
cobertura (Ridder, 1909: 1425), o que não é consensual (Züchner, 1942). De modo geral, parece que na Grécia egeia os espelhos de caixa sucederam os espelhos de mesa, sem que haja uma ruptura clara, ocorrendo mais tarde, entre gregos da Magna Grécia, uma evolução morfológica e ornamental posterior, tardo-clássica e proto-helenística, que não será aqui analisada (Vergara, Cerqueira 2018).

Os espelhos de caixa se compunham do fundo e cobertura; as superfícies internas, polidas, eram usadas para contemplar a imagem refletida, sendo uma das superfícies levemente côncava, outra, levemente convexa (Fig. 16b). Em uma expressiva parte destes espelhos, a cobertura, na parte externa, era ornamentada com uma imagem moldada em relevo (Fig. 16a). Em um número mais reduzido de exemplares, a parte interna recebia decoração, gravada por meio de incisão, o que constituía uma técnica muito delicada. A produção dos espelhos com relevo deve ter iniciado em meados do séc. V, estendendo-se até finais do IV. Já a técnica de espelhos gravados gregos, que terá seu apogeu na torêutica etrusca, começa bem no final do séc. V - ressalve-se porém que esta técnica não era desconhecida no Egito tardio, presente por exemplo em espelhos da Baixa Época, da XXV ou XXVI dinastia, pouco anteriores ou contemporâneos ao período arcaico grego $^{9}$. Os principais centro produtores gregos, arqueologicamente documentados, são Corinto, Cálcis, a Jônia e, em menor escala, Atenas (Züchner, 1942), sem que outros centros, como Argos (Fig. 01), tenham deixado de contribuir com esta indústria. A Magna Grécia assimilou esta produção, possuindo uma indústria de espelhos, centrada em Locri-Epizefiri e Tarento, onde se

\footnotetext{
${ }^{9}$ Espelho egípcio de cobre, com cabo de marfim, encaixado em um suporte de bronze. Decoração incisa representa a deusa Mut entronizada em um santuário, disposto acima de duas linhas com inscrições em hieróglifos. Londres, Museu Britânico, EA51067 (1912, 0608.76). XXV-XXVI dinastia (?).
} 
produziram exemplares requintados na combinação entre o bronze, a prata e o douramento ${ }^{10}$.

Sob influência da Grécia e do Sul da Itália, desenvolveram-se os espelhos de bronze etruscos, na sua grande maioria espelhos de mão, apesar de produzirem também os outros tipos. Ao contrário da Grécia, onde predominavam os espelhos de caixa com relevo, na Etrúria estes são evidenciados em menor número. Os etruscos se notabilizaram, assim, pela produção, em larga escala, de espelhos de mão gravados com incisão, representando preferencialmente motivos da mitologia grega, sendo menos comuns os temas enraizados em tradições culturais de matriz etrusca. Eventualmente, aparecem espelhos de caixa em formato quadrado, dando início a esta forma que se popularizará mais tarde em Roma (Ridder 1909: 1428-29). Os romanos herdaram as tradições da torêutica grega e etrusca, mas diversificaram os materiais usados, sendo muito comum o uso do estanho, assim como do cobre, ou peças de ainda maior valor, feitas de prata, como os espelhos encontrados em Pompeia.

\section{O referente "espelho" na pintura dos vasos áticos}

Uma das mais antigas representações do espelho na pintura de vasos ocorre sobre um skyphos ático de figuras negras do final do séc. VI, com representação do julgamento de Páris ${ }^{11}$. O pintor colocou o espelho na mão de Afrodite, de sorte que se tornou bastante popular "como atributo e sinal de identificação de Afrodite, assim designada como vencedora no concurso de beleza" (Balensiefen, 1990: 31). No entanto, salvo a conexão com Afrodite, a maioria das cenas com representação de espelho se reportam a contextos da vida diária.

Na alusão ao cotidiano, os pintores de vasos áticos de figuras vermelhas apresentam o espelho em clara conexão com o gênero feminino. Porém, esta associação não é feita de modo homogêneo. Quando observamos as cenas de gineceu, e outra sorte de cenas protagonizadas por figuras que se referem à fração feminina do corpo de cidadãos, e, mais ainda, de sua elite, constatamos que, entre o conjunto de objetos retratados nestas cenas, como alusão a aspectos materiais e simbólicos deste contexto social e cotidiano, a visibilidade do espelho não é das mais acentuadas, na contramão de outros objetos, como canastras, kalathoi e mesmo o trigonon

10 Espelho em caixa com relevo. Prov.: Canosa. Tarento, Museu Arqueológico, inv. 22436. Züchner, 1942, KS 154, Abb. 43.

11 Skyphos ático de figuras negras. Atenas, Museu Nacional, 12.626. c. 510-500. Cf. Lekythos ático de figuras negras. Laon, Musée Municipal, 37.894. c. 500-490. 
(harpa), cujas figuras são agenciadas para simbolizar o espaço de dignidade da mulher cidadã, noiva ou esposa, numphe ou gune (Fig. 04 e 05) Num inventariado de mais de cinquenta vasos com cenas de divertimento musical no gineceu ou de comemorações domésticas ligadas às núpcias, nomeadamente a epaulia ${ }^{12}$, constatei a raridade do espelho nestas cenas. Uma das poucas exceções se encontra em uma hydria do Pintor de Kleophon (Vergara Cerqueira, 2001: cat. 312) ${ }^{13}$.
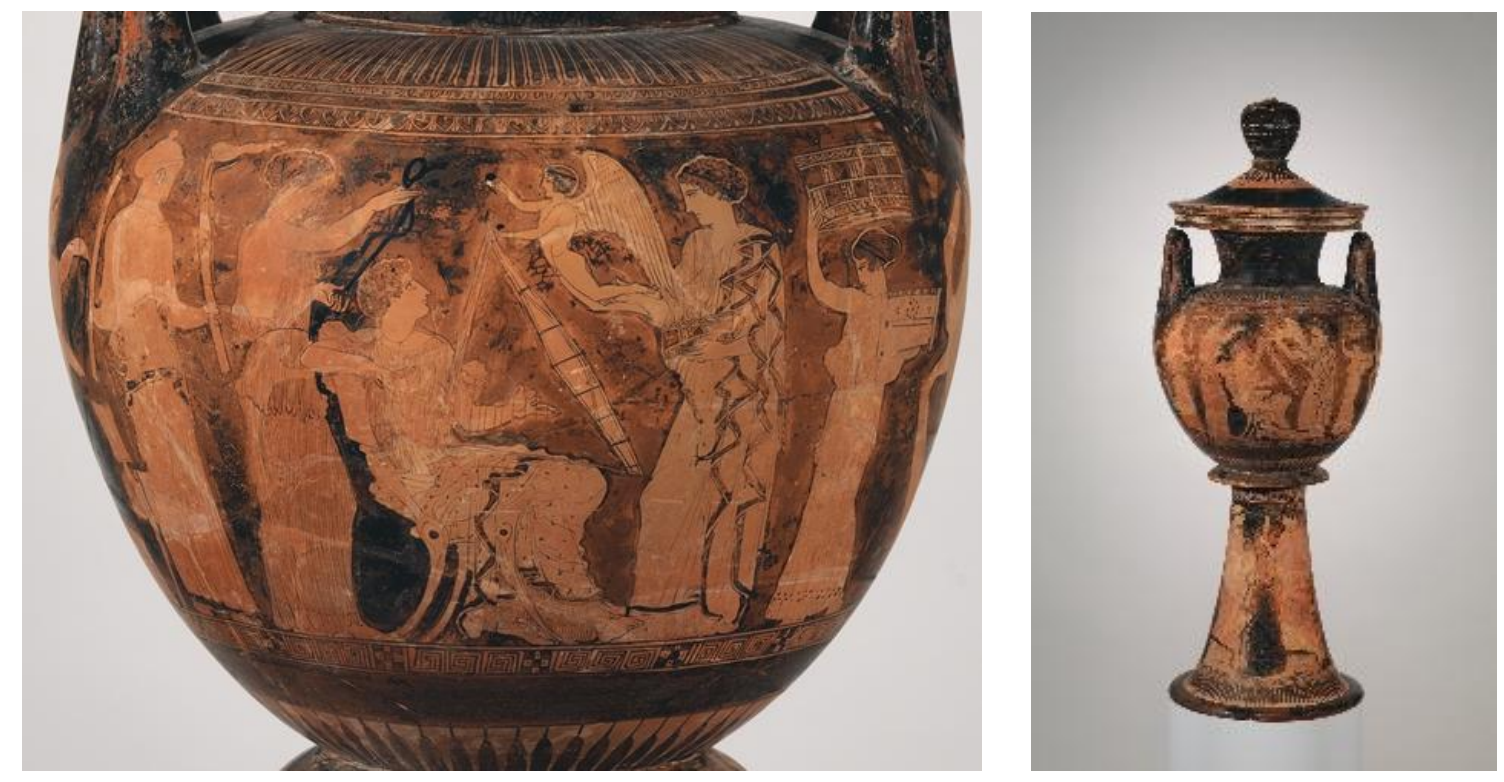

Fig. 4. Lebes gamikos ático de figuras vermelhas. The Washing Painter. Nova Iorque, Metropolitan Museum of Art, 16.73. Cwww.metmuseum.org

Mas veja bem: não podemos afirmar que o espelho estava ausente da rotina do gineceu. Ele aparece, de fato, desde o final do primeiro quartel do séc. $\mathrm{V}$ em vasos em que o espelho, segundo interpretação de L. Balensiefen, vai além de atributo de gênero. Estas cenas mostram mulheres cuidando de si diante do espelho14, "mas não podem ser definidas como imagens puras de gineceu ou de toalete, pois nelas

12 Celebração quando a noiva, após efetivada a união, recebe parentes e amigas que trazem presentes destinados à sua vida conjugal.

${ }_{13}$ Hydria ática de figuras vermelhas. Pintor de Kleophon (ARV2 1147/62). Munique, Antikesammlung, 6452. c. 430 a.C. Bib.: CVA Munique 5 (Alemanha 20) pr. 231.2 e 9. Em nosso inventário com cenas musicais no gineceu, que perfaz 54 vasos, incluindo cenas de divertimento musical (34 vasos) e de epaulia (20 vasos), o espelho está presente em apenas dois vasos.

14 1) Lekythos ático de figuras vermelhas. Círculo de Brygos (ARV2 384/214). Boston, Museum of Fine Arts, 13.189. c. 480 a.C. 2) Hydria ática de figuras vermelhas. Pintor de Alkimachos (ARV2 1608). Atenas, Coleção Kanellopoulos. c. 470 a.C. A hydria ateniense é considerada a primeira representação da imagem refletida no espelho perfeita do ponto de vista físico da ótica. 
domina uma atmosfera no geral erótica, até mesmo erótico-dionisíaca" (Balensiefen, 1990: 29). Portanto, sua significação extrapola a ideia do gineceu como lugar de recolhimento e proteção feminina, de dedicação ao convívio com parentes e amigas, onde se ocuparia com atividades necessárias à economia da casa, como a tecelagem, mas também atividades lúdicas, como entretenimentos musicais (Maffre, 1989: 128. Kunze-Götte, 1957). Trata-se outrossim de cenas que conotam a iniciação amorosa, compatível com algum ritual relacionado a Eros, abordagem que se tornará muito comum na iconografia dos vasos ápulos da segunda metade do século IV (Schneider-Herrmann, 1977: 29, 38; 1970).
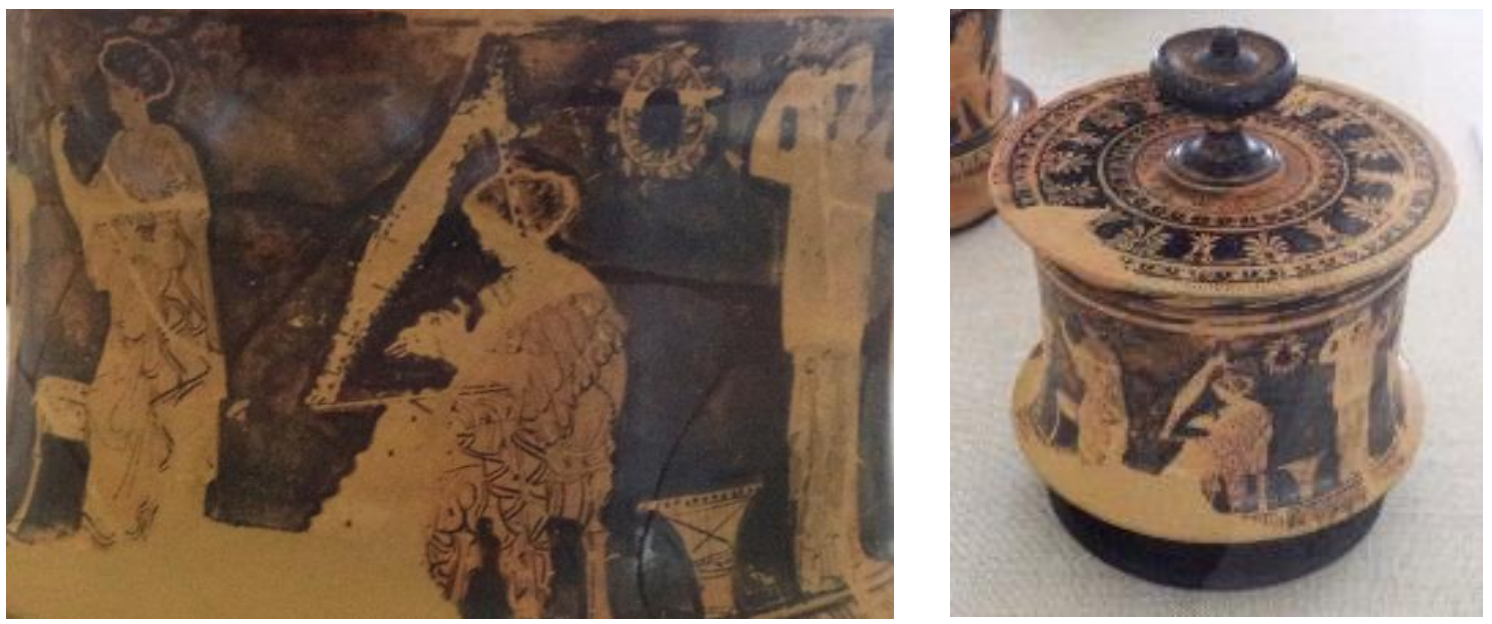

Fig. 5. Cena no gineceu - Pyxis ática de figuras vermelhas. The Washing Painter. Würzburg, Martin von Wagner Museum, 541. CFoto: Fábio Vergara Cerqueira (2014)

Percebe-se então um tratamento especial e cuidadoso do espelho na iconografia de cenas domésticas da mulher cidadã: frequente em cenas de cuidado pessoal com conotações eróticas e iniciáticas ${ }^{15}$, raro em cenas que retratariam a dignidade da condição social de esposa, como os "concertos musicais no gineceu", expressão de Erika Kunze-Götte, e as cenas de epaulia. Ora, esta é uma organização da representação da cultura material

15 1) Cena de depilação das partes íntimas femininas: Cratera ática de figuras vermelhas. Pintor do Dinos. Cambridge (MA), Harvard University, Arthur M. Sackler Mus. Terceiro quartel do séc. V (Eros agachado depila uma mulher nua, de pé, diante dele, enquanto outra, à esquerda, sentada, depila a si mesma; no campo, um espelho). Kreilinger, 2007, 271, fig. 14a. 2) Mulher nua olhando-se no espelho: Kylix ática de figuras vermelhas. Basileia, mercado de arte. Em torno de 460 a.C. (mulher nua, entre louterion e diphros, sobre o qual repousa sua vestimenta, observa-se no espelho). Kreilinger, 2007, 280, fig. 60. MüM, Kunstwerke der Antike, Sonderlist R, 1977, n. 58. 3) Mulher tomando banho no louterion: Cratera ática de figuras vermelhas. Pintor da Centauromaquia do Louvre. Dresden, Staatliche Kunstsammlungen, ZV 797. Terceiro quartel do séc. V. (mulher nua, dentro da cuba, em que se lê a inscrição $K A \Lambda H$, banhando-se, acompanhada por uma mulher nua à esquerda e outra vestida à direita, a qual segura um espelho). (Kreilinger, 2007, 284, fig. 78.) 
efetuada no campo do simbólico, conferindo uma maior presença ou ausência do objeto "espelho" conforme a natureza simbólica da cena.
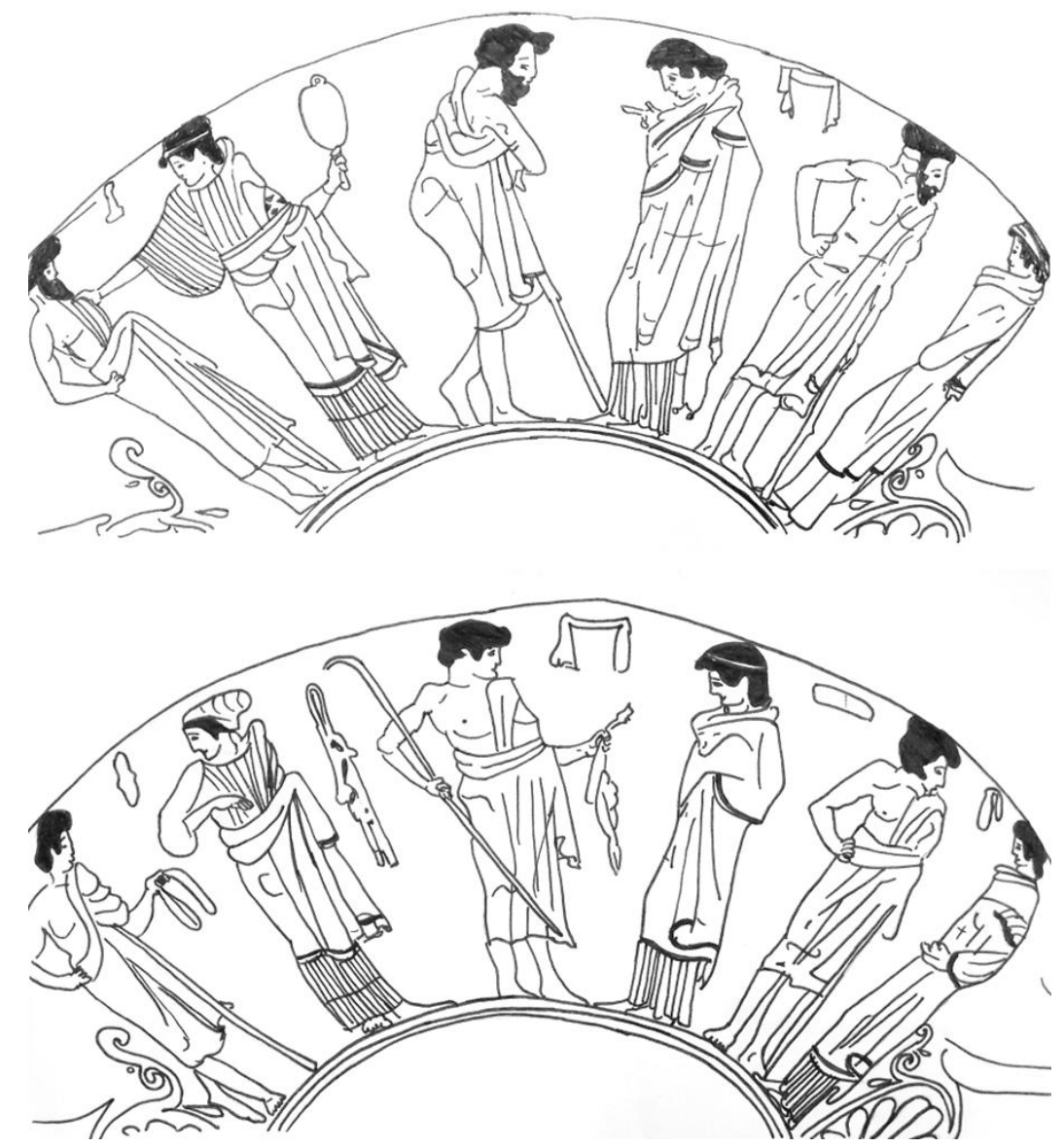

Fig. 6. Homens adultos e jovens visitam o ergasterion ou porneion. Uma hetaira segura um espelho: Kylix ática de figuras vermelhas. Pintor de Splanchnoptes. Osaka/Sakai, Coleção Oka, 13. Fonte: CVA Japão 2, pr. 32.1-3; pr. 33.1-3. Desennho: Lidiane Carderaro (2018).

Por outro lado, quando os pintores de vaso se deslocam do espaço doméstico da mulher cidadã para o espaço das hetairas, atributos femininos como a canastra e o kalathos praticamente saem de cena. Em seu lugar, o pintor faz uma alternância entre atributos iconográficos masculinos e das hetairas: de uma parte, objetos ligados às palestras e ginásios (esponja, estrígilo e díptico) ${ }^{16}$, sugerindo que homens adultos e jovens os trouxessem quando voltavam da prática atlética e escolar realizada nestes locais; de outra, objetos como o aulos (muitas vezes

\footnotetext{
16 Kylix ática de figuras vermelhas. Makron. Toledo, Toledo Museum of Art, 72.55. Primeiro quartel do séc. V. CVA Toledo 1 (EUA 17) pr. 53-4.
} 
substituído visualmente por seu estojo, a chamada sybene) ${ }^{17}$ e o próprio espelho, frequente nestas cenas (Fig. 6). Comparando os repertórios por nós inventariados de cenas domésticas de mulheres cidadãs e cenas de prostíbulo, proporcionalmente o espelho aparece quatro vezes mais em cenas com hetairas (Vergara Cerqueira, 2001: 515-539).

Ora, de forma inversa ao colocado mais acima, é também improvável que as hetairas em sua rotina não possuíssem kalathoi e canastras para suas necessidades cotidianas de produção das próprias vestimentas e acomodação de roupas e pertences. A sua ausência é simbólica; e o reforço da presença do espelho, do mesmo modo, também o é.

Constata-se que o sistema simbólico cerzido ao longo do tempo pelos pintores de vasos áticos organiza, com base numa intersecção entre gênero e condição social, uma espécie de zoneamento de atributos iconográficos femininos. Neste sistema, o espelho, não obstante seja na esfera cotidiana um item de uso feminino, é mobilizado visualmente como um atributo específico da condição social de hetaira. Seu simbolismo erótico, assim, se sobressai a outros possíveis simbolismos, ritualísticos, místicos ou funerários - simbolismos estes muito raros na iconografia dos vasos áticos, mas sistematicamente presentes na iconografia dos vasos ápulos de figuras vermelhas do século IV.

Entretanto, uma vez que os realia testemunham que os espelhos gregos são portadores de rico repertório iconográfico em suas superfícies, é proveitoso, para a melhor compreensão dos sentidos deste objeto na cultura grega, que estudemos esta iconografia - no caso, a iconografia presente nos espelhos.

Iconografia nos espelhos gregos, por relevo ou incisão (Cálcis, Atenas, Corinto e Jônia)

A relação do espelho com o domínio erótico do prazer sexual físico, ligado diretamente às hetairas, tópica verificada na pintura dos vasos áticos, exerce influência sobre a iconografia representada sobre as próprias superfícies do objeto espelho. Bom exemplo disto está evidenciado em um espelho de Corinto, que replica cenas de symplegma (coito explícito) na cobertura da tampa, em relevo, e na parte interna desta, gravado com incisão (Fig. 7a-b) (Züchner, 1942: 66, KS 95).

\footnotetext{
17 Chester Starr (1978) coloca que o domínio da técnica do aulos era um diferencial para uma hetaira, posto que aquelas que fossem ao mesmo tempo auletridai eram as mais bem remuneradas.
} 
Contudo, o significado amoroso associado ao espelho é tratado precipuamente através de cenas extraídas do repertório mitológico, inspiração predominante da iconografia dos espelhos gregos. Dois espelhos produzidos em Cálcis, na Eubeia, exemplificam esta conotação amorosa. Em um espelho conservado em Berlim, datado aproximadamente de 375 a.C., o relevo da cobertura mostra o rapto de Ganimedes por Zeus, disfarçado de águia (Züchner, 1942, 62, KS 86, Taf. 7) (Fig. 8) ${ }^{18}$. Esta mesma narrativa, segundo Plínio (N.H. XXXIV.19.17), foi objeto da atenção, na mesma época, do escultor ateniense Leochares, ativo entre 370 e 320, que se notabilizou, na Antiguidade, entre outras obras, pelo seu grupo escultórico representando Zeus, em forma de águia, levando Ganimedes (Brodersen, Zimmermann, 2006: 335). É bem provável, então, que a abordagem do mito reproduzida neste espelho calcídico reflita o impacto da obra do escultor ateniense, nela se inspirando. Mas não é fácil dissociar esta temática de uma apologia do homoerotismo pederástico, o que a princípio seria relativamente paradoxal com a pressuposta exclusividade feminina do "mundo do espelho".
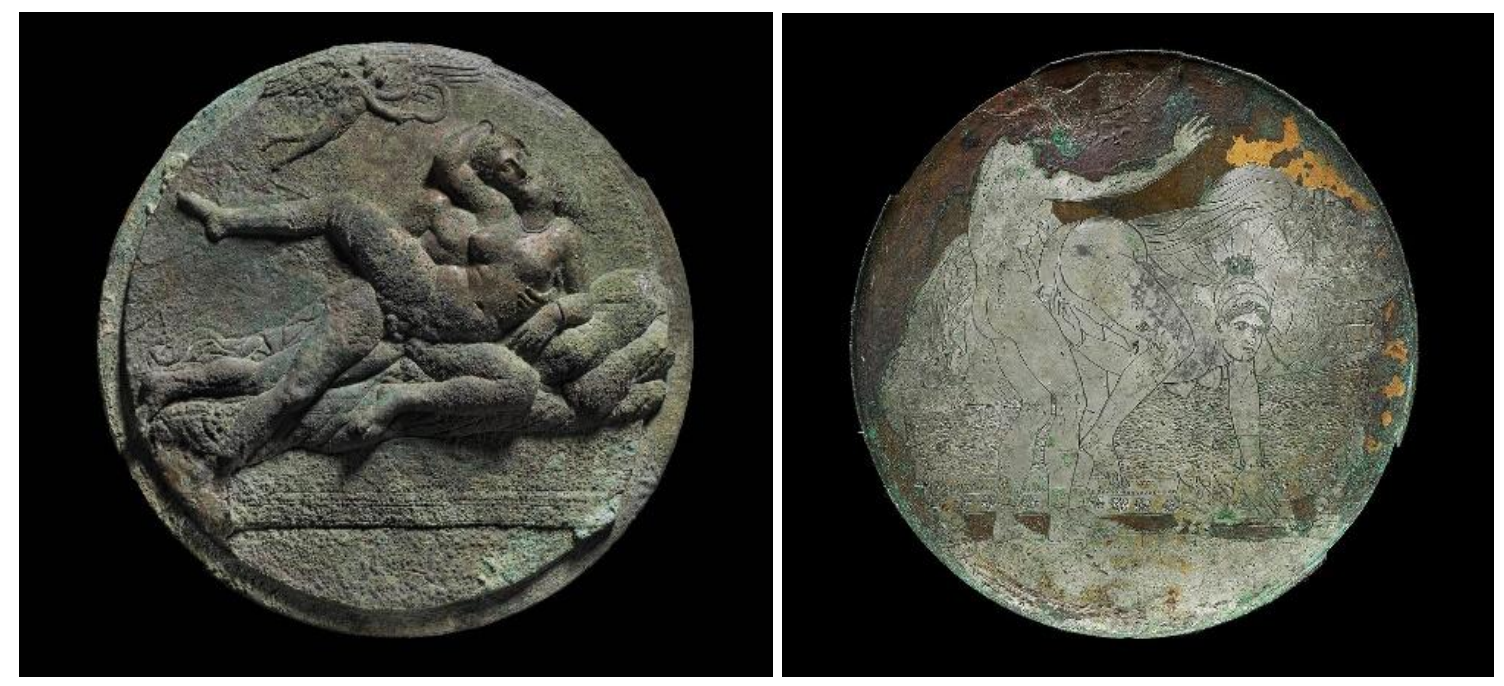

Figura 7a-b. Esquerda: Relevo: Eros e cena erótica (symplegma). Direita: Gravação: Cena erótica (symplegma). Espelho de caixa. Bronze. Produzido em Corinto. Boston, Museu de Belas Artes, RES.08.32c.2 Ca. 340-320 a.C. Foto: Cwikicommons (cena interna, incisa)

O segundo, proveniente de Erétria e datado do último quartel do séc. V, é bastante singular: possui superfície polida nas duas placas e duas coberturas com decoração em relevo (Fig. 9a-b). Em uma das coberturas, temos, sentados sobre uma base rochosa, em uma cena de beijo, Dioniso, acomodado sobre sua clâmide, e Ariadne, que o abraça - a presença de

\footnotetext{
18 Fonte: Züchner 1942, 62, KS 86, Taf. 7 (datação: Furtwängler: 400 - 350; Curtius: 350340).
} 
um par de thyrsoi não deixa dúvida sobre a identificação' ${ }^{19}$; a outra cobertura traz uma representação de Afrodite, com Eros pré-adolescente sentado sobre suas pernas. Identifica-se aqui uma associação, no campo da simbologia do espelho, entre Afrodite e Dioniso.

Essa associação entre Dioniso e Afrodite se repete de várias formas na iconografia do espelho, como ocorre na cobertura do espelho de Boston, cujo relevo retrata Afrodite, apoiando-se em um pilar e alcançando um bastão a um pequeno ganso, enquanto Eros voando se aproxima para abraçá-la. Diante dela, à esquerda, sentado em uma pele de pantera, sobre uma base rochosa, um sátiro adulto, ao lado de uma árvore, que estende sua mão à deusa 20 .

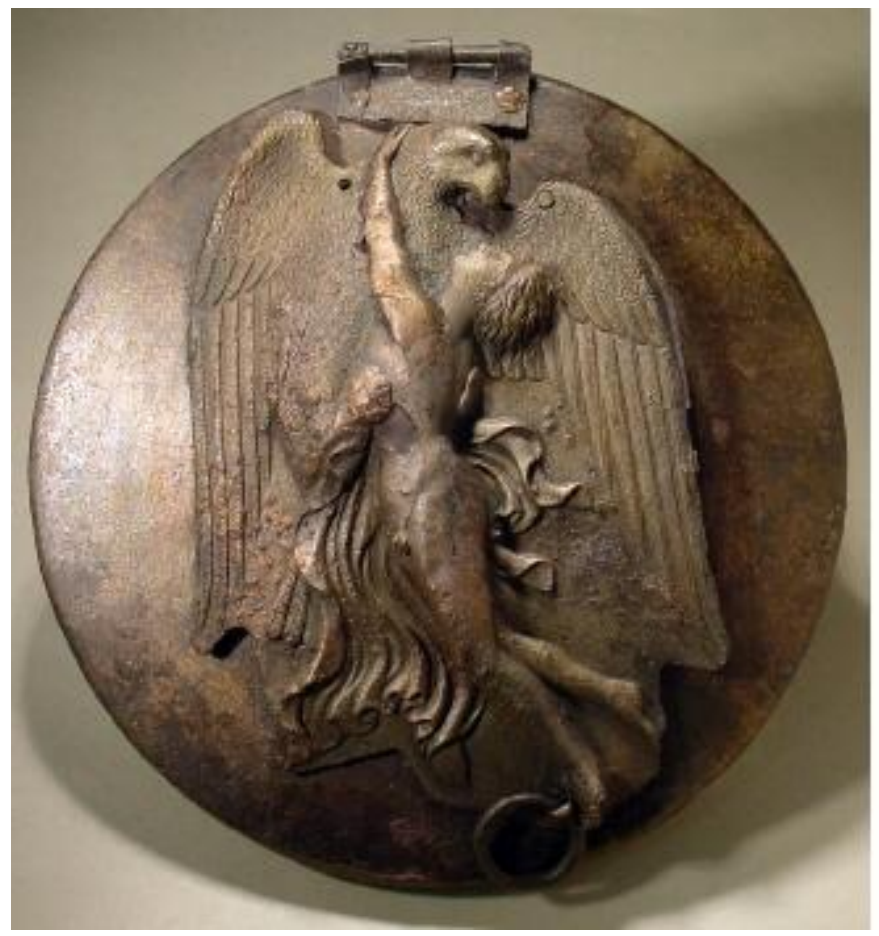

Fig. 8. Zeus (águia) e Ganimedes: Espelho de caixa com relevo. Produzido na Cálcis. Berlim, Antikensammlung, 7928. c. 360-350 a.C. (Züchner). (OFoto: Antikensammlung, Staatliche Museen zu Berlin Fotógrafo: Norbert Franken.

Apesar da variação temática, prioritariamente inspirada em temas mitológicos, com frequência mostrando pares amorosos (Fig. 10)21, a

${ }^{19}$ Este par se repete em outros espelhos, como o exemplar coríntio Boston, Museum of Fine Arts, 01.7513, datado de cerca de 350 a.C. Züchner 1942, 33-34, KS 38, Taf. 19.

${ }^{20}$ Espelho de caixa em bronze. Proveniência indefinida. Boston, Museum of Fine Arts, 01.7494a-c. c. 320 a.C.

21 1) Boreas e Oreithya: Espelho de caixa com relevo. Bronze. Produzido em Cálcis. Proveniente de Erétria. Atenas, Museu Nacional, 7416. Em torno de 350. Züchner, 1942, 62, KS 87. 2) Selene e Endymion: Espelho de caixa com relevo. Bronze. Produzido em Cálcis. Proveniente de tumba de Demetrias. Atenas, Museu Nacional, s./n. Züchner, 
figura predominante sobre as coberturas de espelhos, sejam eles coríntios ou áticos ${ }^{22}$, jônicos ou calcídicos, é Afrodite, às vezes sozinha, mas muitas vezes com Eros, como no espelho calcídico de Erétria. Esta é a combinação mais frequente, que permite variações. Em um espelho conservado em Tübingen, de provável produção coríntia, Afrodite brinca com Eros ${ }^{23}$; já em um espelho jônico do Hermitage, encontrado na península de Taman, no Mar Negro, Afrodite, sentada sobre um diphros, beija o pequenos Eros, segurando-o em seu colo 24 . Em um bom número de exemplares, porém, a deusa está acompanhada de animais, os quais ela cavalga, abraça, acaricia ou alimenta. As aves vinculadas à deusa do amor talvez sejam as mais frequentes. Em alguns casos, os animais representados são indicadores de algum dos epítetos com que Afrodite é cultuada.
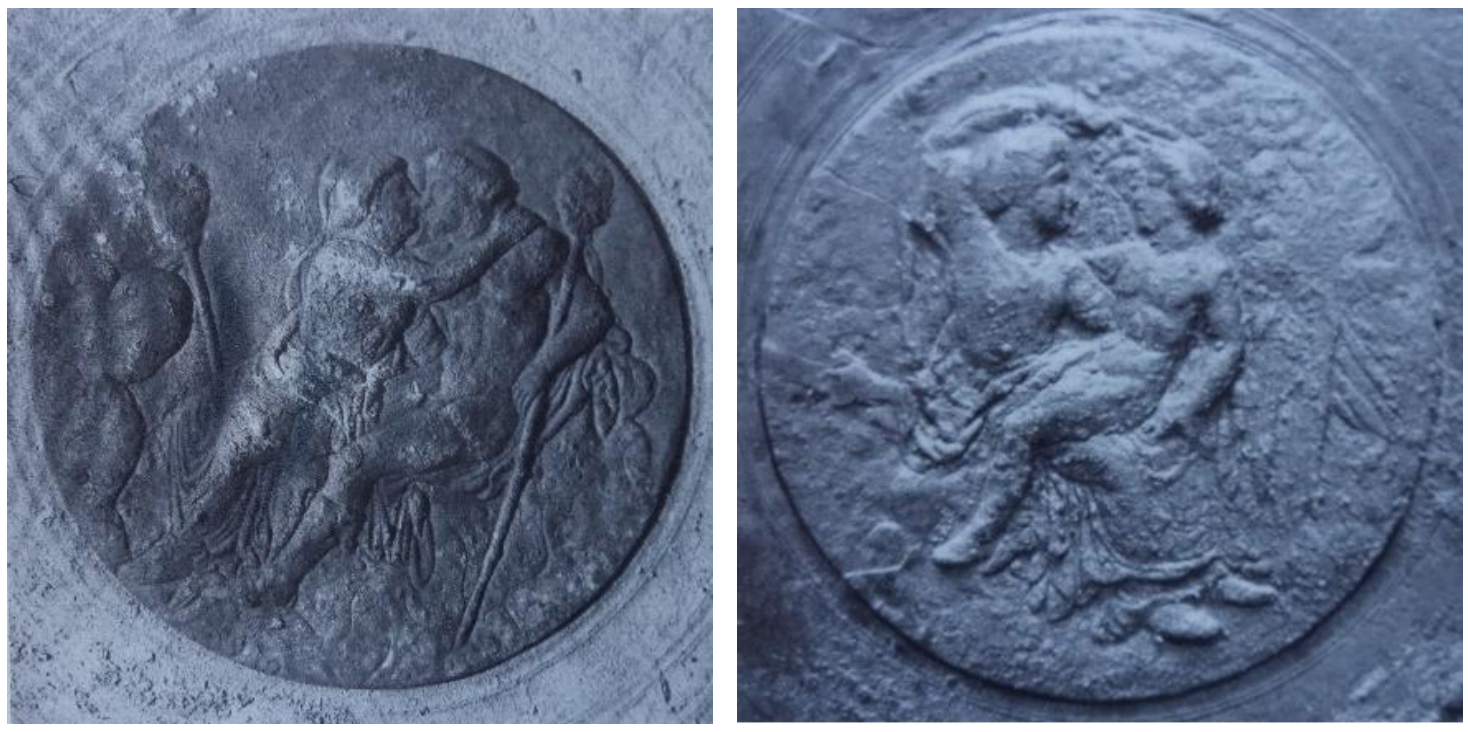

Fig. 9a-b. Dioniso e Ariadne (esquerda). Afrodite e Eros (direita): Espelho duplo de bronze com cobertura decorada em relevo. Produzido em Cálcis. Atenas, Museu

1942, 63, KS 88. 3) Hermes e ninfa: Espelho de caixa com relevo. Bronze. Proveniente de Corinto. Londres, Museu Britânico, 294 (1895,1026.1). c. 300-270 a.C.. Züchner, 1942, 64, K89. 4) Mársias e Olimpo: Espelho de caixa com relevo. Bronze. Produzido em Corinto. Proveniente da região da ilha de Rodes. Nova Iorque, Metropolitan Museum. Em torno de 300. Züchner, 1942, 89-90, KS 150, Abb. 104, p. 190.

22 Espelho de caixa com relevo. Bronze. Produzido em Atenas. Atenas, Museu Nacional, 7678. Em torno de 400 a.C. (Züchner). Züchner 1942, 13 e 222, Abb. 126. (Perdrizet: final séc. V).

${ }^{23}$ Espelho de caixa com relevo. Bronze. Produzido em Corinto (?). Proveniente de Atenas. Tübingen, Archäologisches Museum der Universität, 210. c. 300 a.C. Züchner 1942, 14, KS 16, Abb. 2.

24 Espelho de caixa com relevo. Bronze. Produzido na Jônia. São Petersburgo, Hermitage, Tumba da Sacerdotisa, Grande Blisniza (península de Taman, próximo a Kertsch, Mar Negro, Rússia). c. 340 a.C. (Schefold). Züchner, 1942, 215, KS 11, Abb. 121. 
Nacional, 7670 e 7670a. Último quartel do séc. V. Fonte: Züchner, 1942, 11, KS 10, Taf. 2.2. e 3.2.

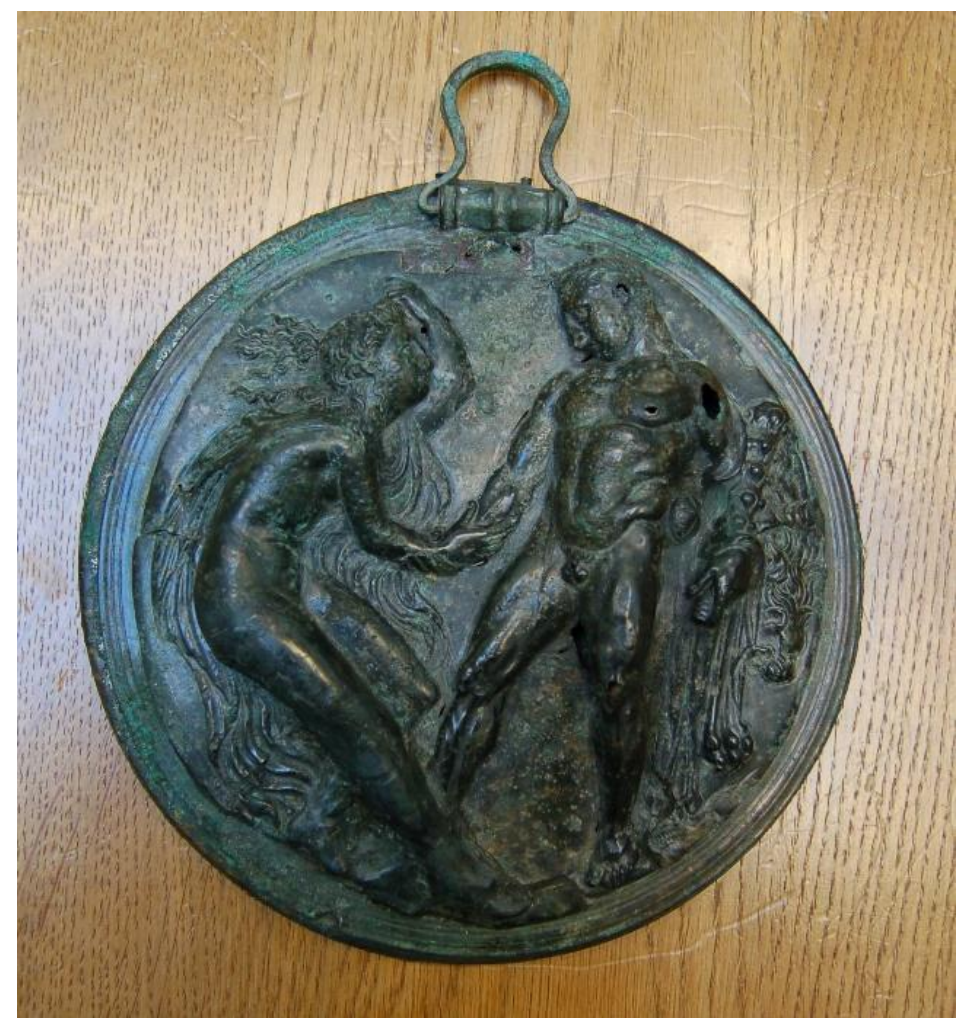

Fig. 10. Héracles e ninfa: Espelho de caixa com relevo. Bronze. Produzido em Corinto. Londres, Museu Britânico, 293 (1892,0719.4). c. 300-280. CTrustees of the British Museum

Em um espelho calcídico conservado em Atenas, um dos mais antigos conservados do tipo com cobertura, proveniente de Erétria, a deusa alcança um recipiente com água (?) a um cisne sobre o qual está sentada (Fig. 11)25. Em outro espelho, é sobre um ganso que a deusa escolhe voar, como em um exemplar coríntio de Paris, encontrado em Erétria e datado do início do segundo quartel do séc. IV (Fig. 12). O ganso reitera a associação a Dioniso apontada logo acima, conotando impulso sexual.

No caso de Afrodite cavalgando um cisne, conforme Ursula Knigge (1982: 161), trata-se-ia de uma evocação do epíteto Urânia. Toma como base a estela Hermitage 1876.102, representando Afrodite sobre um cisne, em que a deusa está identificada, por inscrição, como Afrodite Urânia. Em qualquer dos casos, sobre cisne ou ganso, a ideia seria de um voo, na sua função de unir o terreno e o celestial (Edwards 1984), indicando a função da deusa que une (Rosenzweig 2004).

25 Trata-se de um espelho duplo, com duas coberturas decoradas. Na segunda (Museu Nacional, 7418, Taf. 3.1), está representada Selene sobre um cavalo. Cf. Coleção W. Rome, Inglaterra (1904). Produzido em Cálcis (?). c. 375. Züchner 1942, K3. 

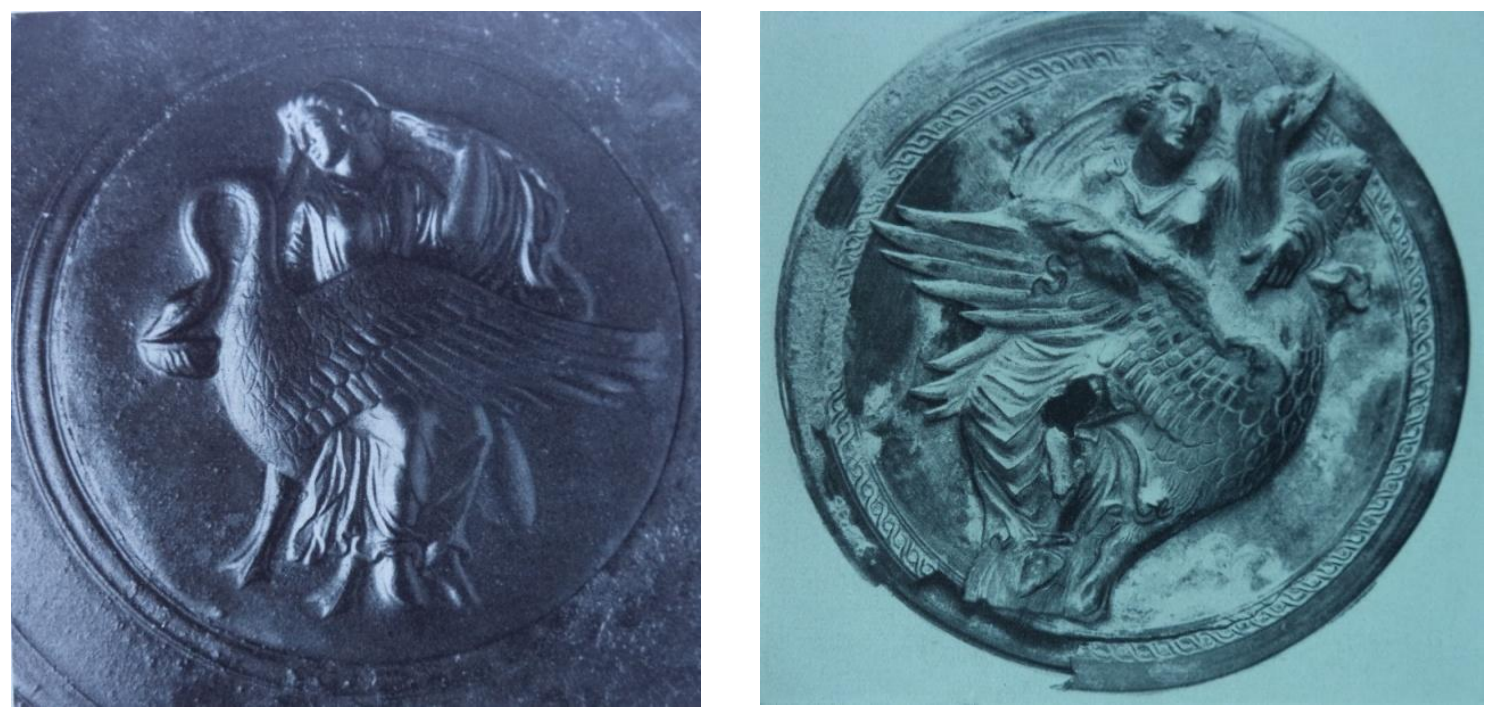

Fig. 11. (esquerda) Afrodite e cisne: Espelho de caixa com relevo. Bronze. Produzido em Cálcis. Atenas, Museu Nacional, 7417. Último quartel do séc. V. Fonte: Züchner 1942, 5-7, KS 1, Taf. 1, Taf. 2.1.

Fig. 12. (direita) Afrodite e ganso: Espelho de caixa com relevo. Bronze. Produzido em Corinto. Proveniente de Erétria. Paris, Louvre, 1706. Pouco posterior a 375. Fonte: Züchner 1942, 7, KS 2, Taf. 5.1.

Não são poucos os espelhos em que Afrodite cavalga um bode. Em um exemplar coríntio de Paris26, a deusa está sentada sobre o animal, que galopa para a direita, acompanhado por seus cabritinhos. Apesar dos chifres assemelharem-se aos de um carneiro, a barba e o pescoço deixam claro que se trata de um bode, animal sagrado da deusa. A cena tem muito movimento: segurando-se com a esquerda no pescoço do bode, com a outra mão leva seu lenço esvoaçante, que cobre parcialmente sua cabeça. Aqui evoca-se, pelo lenço esvoaçante, que Afrodite fará um voo sobre o bode. Mas, mais que isso, a presença dos cabritinhos indica sua qualidade de deusa da procriação e da fertilidade. O tema se repete em relevos votivos dedicados à deusa em seu templo situado na ágora de Atenas, como o relevo Agora S 1797 (Edwards 1984: pr. 17b), mostrando sua popularidade, como deusa tida como propiciadora de fertilidade, razão pela qual era cultuada tanto por hetairas, como comprova o

${ }^{26}$ Espelho de caixa com relevo. Bronze. Produzido em Corinto. Proveniente da região de Palestrina, no Lácio. Paris, Louvre, 1707. c. 375 a.C. Züchner, 1942, 07-08, KS 4, Taf. 6. Outros exemplares com bode: 1) Atenas, Museu Nacional, 7421. Cálcis, prov. Erétria, c. 350. Züchner, 1942, 08-09, KS 5. 2) Berlim, Antikesammlung, 8064.161. Cálcis, prov. imprecisa (Beócia ou Lócris), segunda metade do séc. IV. Züchner, 1942, 09-10, KS 6. 
medalhão de prata da Construção Z 3 da ágora27, como por mulheres livres, noivas ou esposas (Edwards 1984: 68. Rosenzweig 2004: 80-81).

Ursula Knigge (1983: 164-165) defendeu a tese de que o bode corresponderia a um símbolo iconográfico de Afrodite Pandêmia, epíteto sob o qual se cultuaria uma deusa popular, do amor carnal, em oposição à Afrodite Urânia, epíteto de deusa celestial, casta, do amor etéreo, sublime, mas também do amor respeitoso, matrimonial, que seria simbolizada pelo cisne ${ }^{28}$. Rachel Rosenzweig (2004: 72 sq) e Charles Edwards (1984: 69, nota 64) não endossam o modelo de identificação iconográfica proposto por Knigge, entendendo que o bode é comum às duas acepções da divindade, uma vez que a tradição estabelecia, desde a introdução do culto à Afrodite em Atenas por Egeu, que em seu ritual the deviam ser sacrificados bodes-fêmea. Para Rosenzweig (2004: 80), Urânia e Pandêmia são apenas epítetos que enfocam aspectos diferentes da mesma e única divindade. Neste sentido, não se deveria dar tanto crédito à dicotomia apresentada por Diotima a Sócrates (Symp. 180d-181), de uma Afrodite vulgar e outra celestial, pois esta dicotomia seria apenas um recurso retórico usado por Platão.

Pandêmia, assim, possuía um duplo caráter. De um lado, a deusa dos prazeres incontroláveis, assim cultuada em Corinto, vulgar do ponto de vista da classificação exposta por Diotima a Sócrates; mas era também, em outra acepção, a deusa que unia os habitantes da pólis em torno de um corpo político unido. Com esta atribuição era cultuada em Atenas, juntamente à Peithó (convencimento, persuasão), culto que se acreditava ter sido introduzido por Teseu à época do sinecismo (Paus. I.22.3). Nesta acepção, era uma deusa política, políade (Burkert, 1977: 242).

\footnotetext{
$27 \mathrm{O}$ pequeno medalhão de prata encontrado na Construção $Z 3$ - parte de um estabelecimento com vários cômodos, situado junto ao Portão Sagrado, lindeiro com as muralhas, e habitado por prostitutas, muitas delas escravas estrangeiras - consiste em um entre tantos objetos encontrados nesta construção que denotam a devoção das hetairas a deusas do amor, não somente Afrodite, mas também deusas estrangeiras. Sua rica iconografia representa os filhotes do bode-fêmea, evocando também o poder de procriação da deusa, mais marcado em seu aspecto de Afrodite nos Jardins (Rosenzweig, 2004: 78. Lind 1988: 166).

28 Platão, no Banquete (Symp. 180d-181), estabelece esta dicotomia, que consiste em uma oposição filosófica e moral entre as duas Afrodites, distinção que teria sido revelada a Sócrates por Diotima. De certo modo, estabelece uma classificação submetida à ordem do logos, da dialética, submetendo a um modelo racional à classificação entre duas formas de amor, uma virtuosa, outra viciosa. Vale refletir até que ponto devemos levar a sério esta dicotomia do ponto de vista religioso, quanto ao lugar da divindade nas crenças comuns, no caldo de cultura religioso.
} 
Nos primórdios, conforme Pausânias (I.14.7), Egeu teria introduzido o culto de Afrodite Urânia em Atenas; mais tarde, seu filho teria adotado o culto a Afrodite Pandemos (Paus. I.22.3), o que reforçaria seu caráter político de deusa que une, política. Assim, seria cultuada como deusa "de todos os demoi" da Ática unidos na pólis de Atenas. Esta função de deusa que une não é discrepante da qualidade de harmoniosa e harmonizadora, presente no epíteto Urânia (Edwards, 1984. Rosenzweig, 2004).

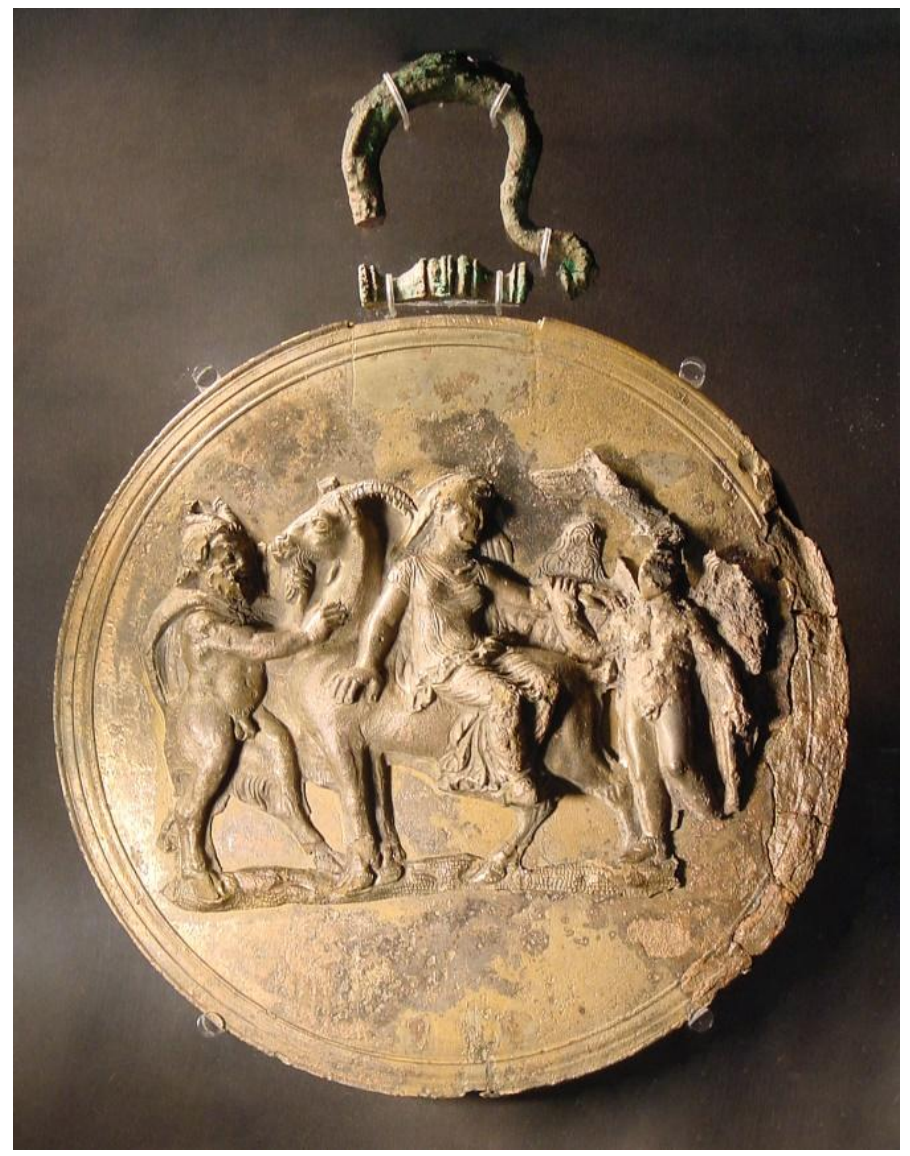

Fig. 13. Afrodite Epitragia (sobre bode-fêmea), entre Pã e Eros: Espelho de caixa com relevo. Bronze. Berlim, Antikesammlung, 8393. Corinto, prov. Erétria, c. 375. (CFoto: Antikensammlung der Staatlichen Museen zu Berlin - Preußischer Kulturbesitz Fotográfo: Norbert Franken

Desde os primeiros tempos, em Atenas, o animal sacrificado teria sido o bode-fêmea (Plut. Thes. XVIII). Em razão desta associação cultual, Afrodite é conhecida também como Afrodite Epitragia, recordando a história contada por Plutarco, de que, ao ser feito o sacrifício por Teseu, a fêmea teria se convertido em macho. A prática era sacrificarem-se dois bodes-fêmeas brancos à Afrodite Pandêmia (Lucian Dial. Meret. VII. Theocrit. Epigr. 13).

É como Epitragia que a deusa é lembrada nestes espelhos que a mostram com o bode. O esquema iconográfico havia sido consagrado pelo escultor 
atuante à época, o célebre Escopas de Paros (420-350), que confeccionou uma estátua da deusa em bronze, montada sobre um bode, para o templo de Afrodite de Élis, no qual haveria também uma estátua de Afrodite Urânia, em marfim e ouro, de autoria do escultor ateniense Fídias (500/490-432), com um pé sobre uma tartaruga (Paus. VI.25.1-2). É possível que as representações sobre os espelhos reflitam influência da escultura de Escopas, mas é igualmente possível que o escultor de Paros quanto os artífices dos espelhos bebam na mesma fonte.

Uma variação do tema da Afrodite Epitragia com o bode encontra-se em um espelho fabricado em Corinto, encontrado em Erétria, e conservado em Berlim (Züchner, 1942, 10, KS 7), que representa a deusa cavalgando o bode-fêmea entre Eros e o próprio Pã (Fig. 13), novamente aproximandoa do domínio de Dioniso, do desejo descontrolado.

O bode é um animal sagrado compartilhado por Afrodite e Dioniso, ambos o recebem como vítima sacrificial em rituais a eles dedicados ${ }^{29}$, de modo que aqui também se verifica a associação entre estas duas divindades, associação fortemente evidenciada acima no duplo espelho calcídico de Erétria (Fig. 09), que provavelmente açambarcasse o campo místico-religioso do objeto espelho. Portanto, nesta associação, extrapolase a simbologia de beleza que poderia estar conotada na figura de Afrodite. Ou seja, significa mais que isso! A figura dos cabritinhos nos remete à fertilidade, mais uma das atribuições da deusa que a aproxima a Dioniso. Ora, é significativo observar que temas ligados a essas duas divindades são, respectivamente, o primeiro e o segundo mais abordados na iconografia dos espelhos em caixa. M. Nilsson $(1995,377)$ aponta que nas Afrodísias de Corinto ocorreria uma mistura entre o culto de Afrodite e de Dioniso, a qual contribuiria para conferir um caráter mais religioso à festividade, que de resto poderia ser vista sob um ponto de vista menos sagrado, dada a efusiva participação das hetairas nos festejos ao longo da noite. Esta associação nos remete ao campo cultual, de práticas de iniciação amorosa, que se realizavam sob os auspícios destas divindades, sob a manifestação de Afrodite Antheia e Dioniso Antheios, protetores da vida sempre florescente, sob cuja potência se realizavam cultos de iniciação secreta a jovens moças, nos quais Eros atuaria como um mediador entre as duas divindades (Schneider-Herrmann 1977, 29).

\footnotetext{
${ }^{29}$ No altar de Afrodite na ágora de Atenas foram encontrados abundantes restos de bode, sacrificados pela população em geral ou talvez por autoridades públicas (Rosenzweig 2004: 78).
} 

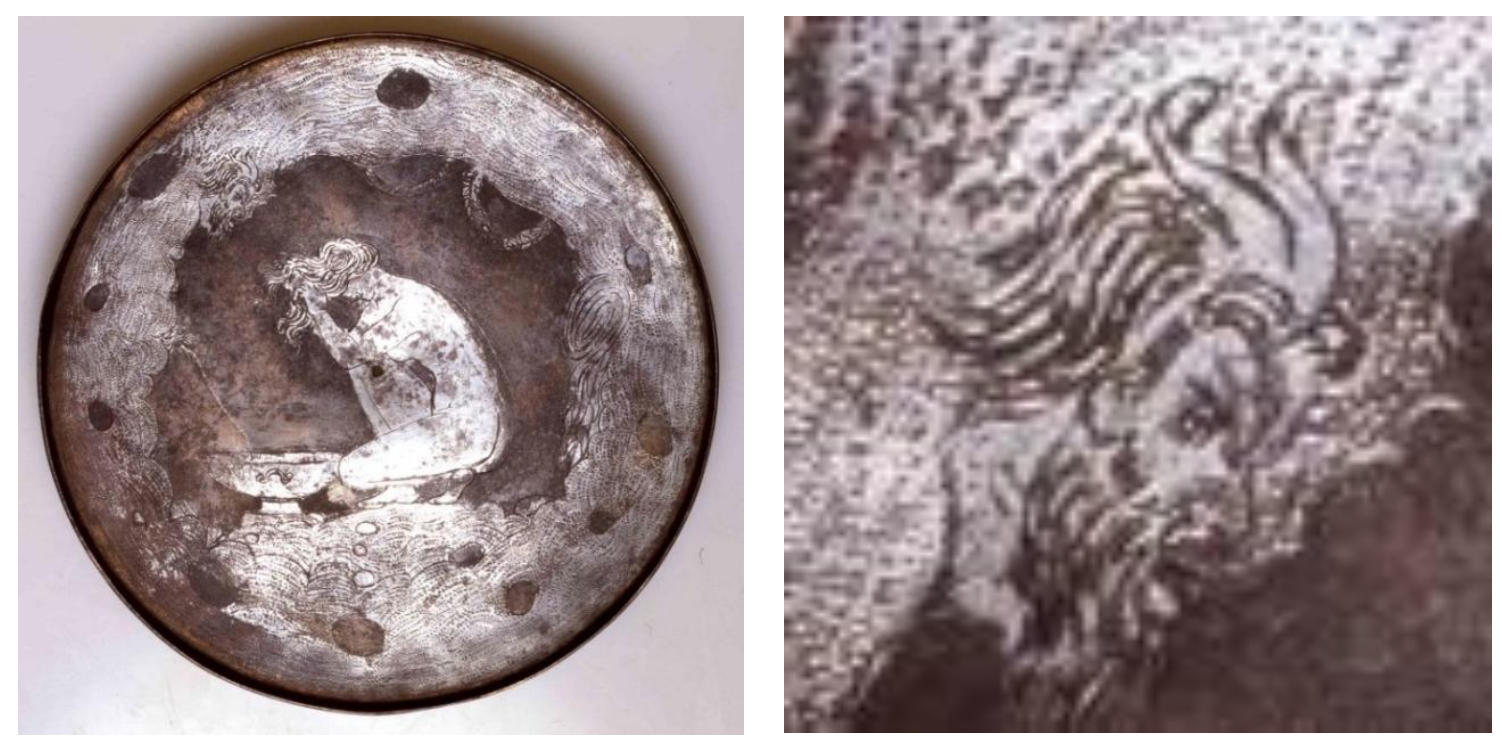

Fig. 14. (à direita, detalhe) Mulher nua lava cabelo junto a uma pequena cuba: Espelho de caixa com decoração em revelo (cobertura) e incisa (superfície interna). Bronze. Produzido em Corinto. Proveniente de Atenas. Berlim, Antikesammlung, 8148. c. 280 a.C. OFoto: Antikensammlung der Staatlichen Museen zu Berlin - Preußischer Kulturbesitz Fotógrafo: Johannes Laurentius
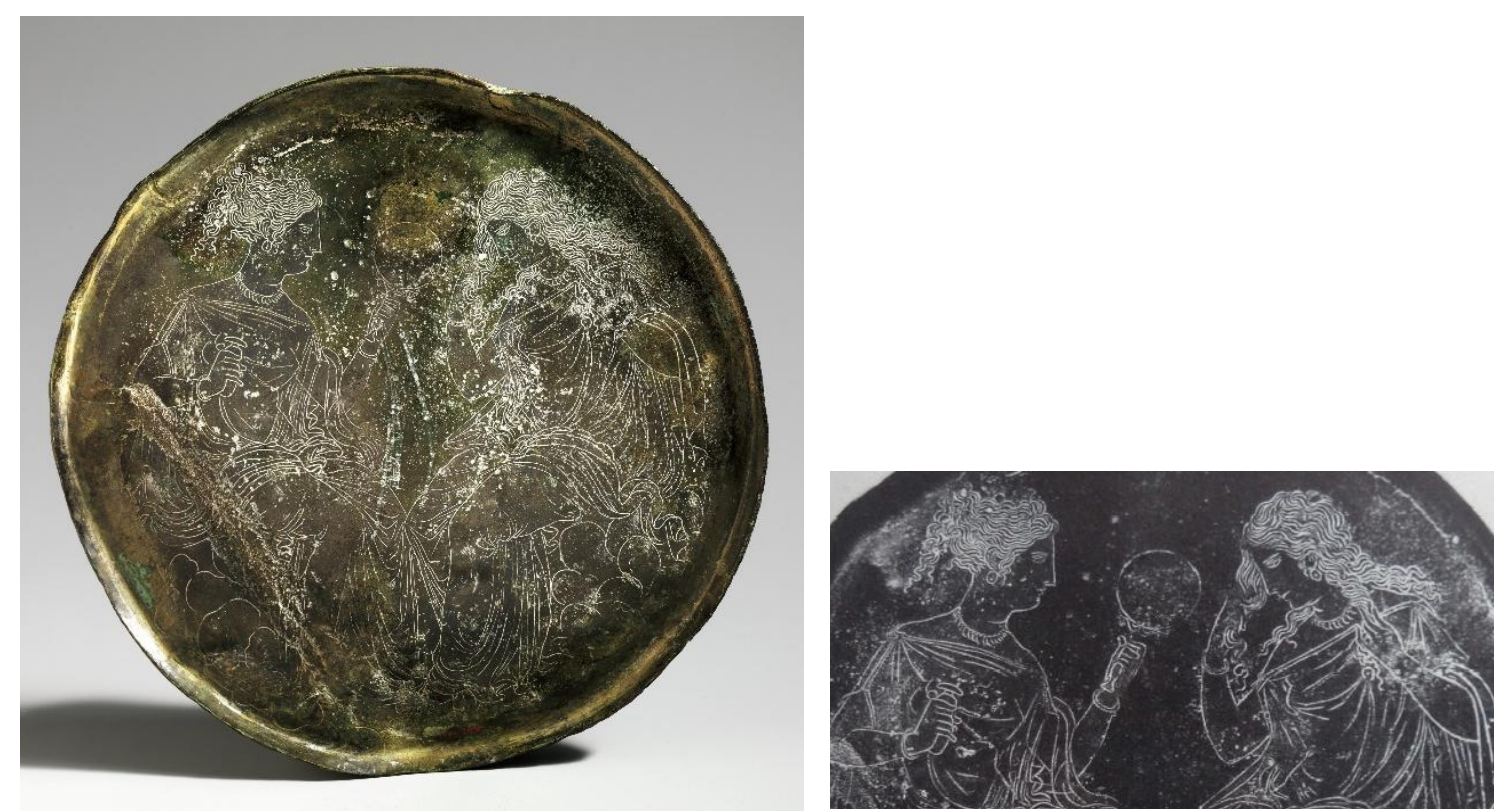

Fig. 15. (à direita, detalhe) Duas mulheres elegantemente trajadas, uma com um espelho e frasco, outra ajeita o cabelo: Espelho de bronze com superfície interna decorada com incisão. Produzido em Corinto. Nova Iorque, Metropolitan Museum, 17.190.2073. Segundo quartel do séc. IV (Schefold: 360-50). Fonte: Züchner, 1942, p. 99100, KS 164, Abb. 98. Cwww.metmuseum.org

Em um número menor de espelhos, a decoração se afasta da simbologia erótica tratada por meio de abordagens mitológicas, e retorna à representação da função prática do espelho, como objeto de uso na toalete 
feminina. A superfície interna de um espelho coríntio de Berlim mostranos, numa gravação por incisão, uma mulher ou ninfa lavando seus cabelos em uma bacia com água, que verte de uma fonte, sendo observada por Pã, havendo uma combinação entre a representação da função pragmática e a simbologia agregada pela figura mitológica de Pã. $\mathrm{Na}$ cena externa, ocorre uma repetição parcial da cena: uma mulher lava os cabelos com água que verte da fonte, junto à bacia, pouco abaixo de uma cabeça de Pã, incorporada à estrutura da fonte (Fig. 14).

A "cena de gênero" pura, vinculada à toalete feminina, ocorre por exemplo em um espelho jônico de Paris, com duas mulheres nuas lavando e ajeitando os cabelos junto a uma cuba (louterion) ${ }^{30}$. Em contrapartida à nudez dos espelhos jônico e coríntio citados acima, um exemplar coríntio de Nova Iorque mostra-nos duas senhoras, elegantemente vestidas, finalizando a toalete. A mulher sentada à esquerda tem na mão direita um pequeno frasco, tipo alabastro, contendor de algum óleo ou perfume, enquanto segura com a esquerda um espelho, aproximando-o da mulher sentada à direita, para que esta possa se olhar enquanto arruma os cabelos (Fig. 15).

O espelho coríntio de Nova Iorque mostra-nos o espelho no espelho, indicando seu uso por mulheres como utensílio caro aos cuidados pessoais femininos. No caso, provavelmente, temos seu uso por mulheres de elevado estrato social, "mulheres-cidadãs". Em um espelho de caixa de Bruxelas, com toda estrutura excepcionalmente bem conservada, vemos, na face decorada em relevo, a própria deusa Afrodite olhando-se no espelho (Fig. 16). O gesto indica seu predicado de deusa da beleza. Aqui Afrodite não é apenas a divindade propiciadora do amor - ela mesma seduz por sua beleza. Ela está em presença de Hermes, a cujo amor cede, em troca de sua sandália. Estão sentados sobre base rochosa, sugerindo um consentimento amoroso, no momento em que um exuberante Eros adolescente se aproxima com um fita, comemorativa do enlace.

Quem sabe o espelho faça ressoar aqui a versão conhecida por Cícero (N.D. 3.22.59), que fazia de Eros filho da união entre Afrodite e Hermes (e não entre a deusa e Ares) ${ }^{31}$. Ao olhar a superfície interior, somos surpreendidos por um motivo ornamental inciso, que nos faz pensar: uma grande estrela, que podemos imaginar reluzente. Inevitável lembrar

30 Espelho de bronze com cobertura decorada em relevo. Produzido na Jônia. Proveniente de Tanagra. Paris, Louvre, 1713. Segundo quartel do séc. IV.

31 "The second was engendered from the sea-foam, and as we are told became the mother by Mercury of the second Cupid". (...) altera spuma procreata, ex qua et Mercurio Cupidinem secundum natum accepimus. (Rachham) 
da constelação Áquila, originada, segundo uma das versões reportadas por (Pseudo-)Hygino, da águia que foi colocada no céu por Hermes como gratificação, por esta lhe ter trazido a sandália de Afrodite, roubada (a pedido de Zeus), enquanto a deusa se banhava no rio Aqueloo (Hyg. Astr. 2.16) ${ }^{32}$. Neste espelho, a simbologia erótica e o fim pragmático estético se fundem, numa mesma imagem.
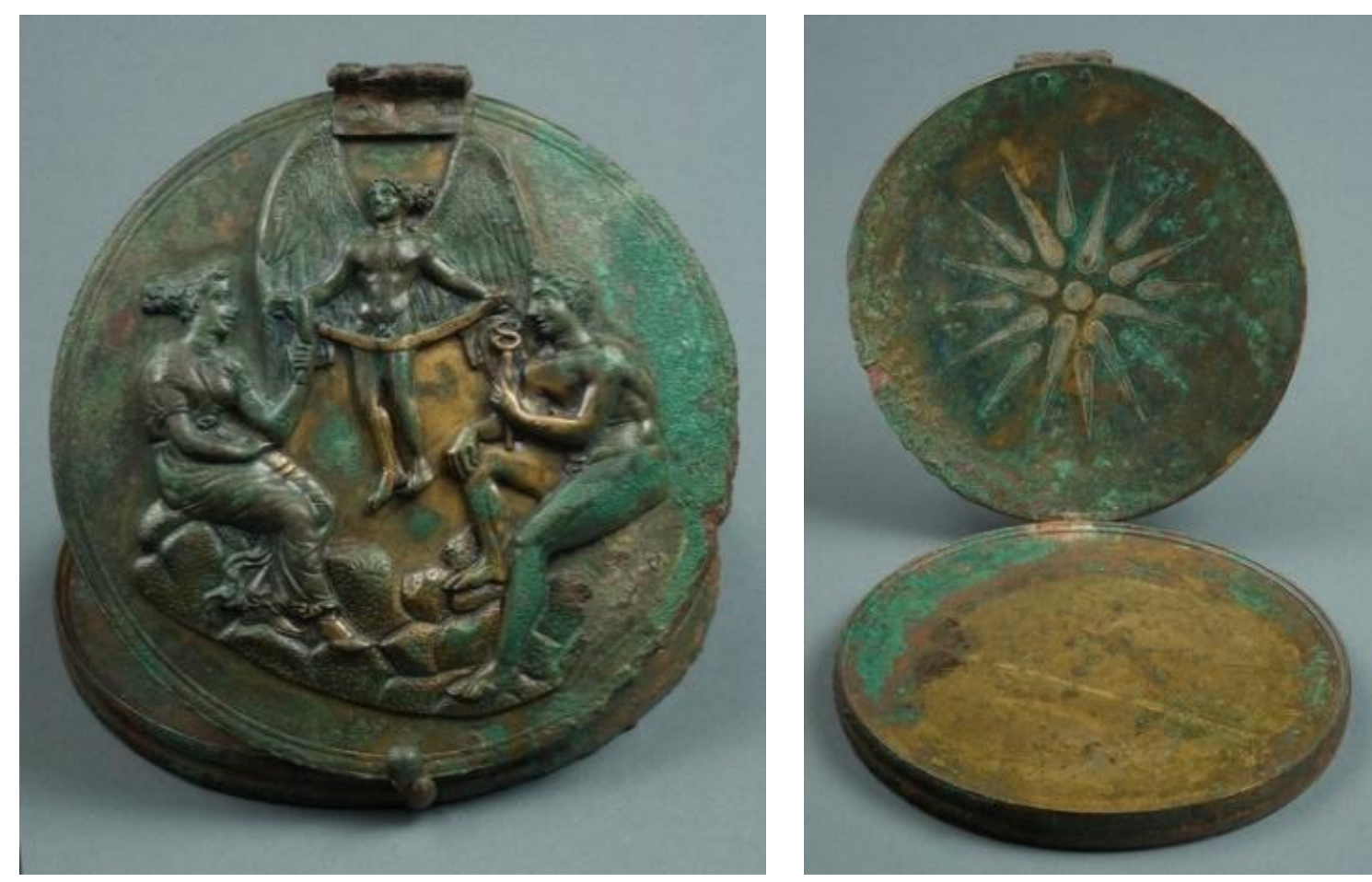

Fig. 16a-b. Afrodite, Hermes e Eros (esquerda). Star (direita): Espelho de caixa, de bronze, com estrutura original preservada, consistindo em um disco polido, articulado à tampa, a qual porta decoração com incisão na parte interna (estrela) e com relevo na cobertura (Afrodite, Hermes e Eros). Produzido em Corinto. Séc. III a.C. Bruxelas, Musée du Cinquantenaire, R.1266. (MRAH-KMKG

32 "Mercurius stirred by Venus's beauty, fell in love with her, and when she permitted no favours, became greatly downcast, as if in disgrace. Jove [Zeus] pitied him, and when Venus was bathing in the river Achelous he sent and eagle to take her sandal to Amythaonia of the Egyptians and give it to Mercurius. Venus, in seeking for it, came to him who loved her, and so he, on attaining his desire, as a reward put the eagle in the sky [as the constellation Aquilla]." Nonnulli etiam dixerunt Mercurium, alii autem Anapladem pulchritudine Veneris inductum in amorem incidisse; et cum ei copia non fieret, animo, ut contumelia accepta, defecisse. Iovem autem misertum eius, cum Venus in Acheloo flumine corpus ablueret, misisse aquilam, quae soccum eius in Amythaoniam Aegyptiorum delatum Mercurio traderet; quem persequens Venus ad cupientem sui pervenit. Qui copia facta, pro beneficio aquilam in mundo locavit. (Grant) 


\section{Considerações finais}

Os espelhos estudados datam de um período que se estende do último quartel do séc. V ao primeiro quartel do séc. III, portanto, cerca de um século e meio. Os exemplares atenienses apresentam as datações mais recuadas, mas não contribuem com muitos exemplares no séc. IV; os calcídicos começam no final do século $\mathrm{V}$ e continuam a ser produzidos por todo o século seguinte; os jônicos, por sua vez, concentram-se no século IV; já os coríntios, apresentam a série mais longa, avançando sobre as primeiras décadas do séc. III.

Interessante observar, nesta cronologia, que boa parte deste período corresponde à produção contemporânea dos vasos ápulos de figuras vermelhas, produzidos majoritariamente em Tarento, cuja atividade se estende até aproximadamente 300 a.C., ao passo que os espelhos estudados podem datar até 270 a.C. A semelhança limita-se porém à cronologia. No que se refere à iconografia e suas implicações quanto ao "mundo do espelho", não há semelhanças, não há correspondência, salvo aspectos pontuais.

A iconografia portada pelos espelhos provenientes das quatro principais indústrias de espelhos gregos (Cálcis, Atenas, Corinto e Jônia) apresenta, entre suas variedades temáticas, um conjunto coerente que se destaca por abordar, de forma mais ou menos direta, a temática amorosa.

Este conjunto, em escala variada, carrega quatro ordens de significação distintas: fim prático (toalete feminina), simbologia erótica ligada à prostituição (cenas explícitas de relação sexual), simbologia amorosa geral (pares mitológicos) e simbologia mágico-religiosa (culto de iniciação amorosa, vinculado à Afrodite, Eros e sob proteção de Dioniso) quantitativamente, são preponderantes as duas últimas modalidades de simbologia amorosa. Contrariamente, no caso da cerâmica ática, produzida entre finais do sexto e inícios do quarto século, predomina a vinculação simbólica do espelho às hetairas, portanto, ao prazer sexual obtido por meio da prostituição, próprio à Afrodite cultuada em Corinto, em cujo santuário era usual que hetairas consagrassem seus espelhos à deusa, ao abandonarem a profissão devido à idade avançada.

No espectro de significações contidas nos repertórios iconográficos registrados das superfícies internas e externas dos espelhos gregos, a simbologia erótica oscila entre duas abordagens: cenas com personagens mitológicas ou com personagens humanas. Entre as cenas amorosas com personagens humanas, há interesse em representar cenas de sexo explícito, que evocam o meio social das hetairas. Entre as cenas com 
personagens mitológicos, ocorrem pares os mais variados: Hermes e ninfa, Héracles e ninfa, Boreas e Oreithya, Selene e Endymion, ou pares homoeróticos, como Zeus e Ganimedes, Mársias e Olimpo. Contudo, há um predomínio notável de cenas envolvendo Afrodite, secundadas por aquelas envolvendo Dioniso.

As cenas com Afrodite ocorrem nas quatro principais indústrias gregas de espelho. A produção ateniense com conteúdo amoroso concentra-se mais nestas imagens com Afrodite e Eros, ou naquelas com Dioniso e Ariadne. A produção calcídica e jônica aprecia as variações de pares mitológicos. As cenas em que o conteúdo amoroso feminino é simbolizado pela representação de ninfas torna-se mais comum no final do séc. IV e início do III. Note-se que as oficinas coríntias, além da maior escala quantitativa e maior extensão cronológica, apresentam também grande variedade temática. É entre os artesãos coríntios que se observa o maior interesse em representar cenas de toalete feminina, variando entre mulheres nuas ou trajadas, incluindo provavelmente hetairas e mulheres cidadãs. São os espelhos coríntios, também, os que representam em maior quantidade cenas de symplegma. Conhecida na Antiguidade como meca dos prazeres e da prostituição, é plausível que este contexto tenha influenciado certas preferências da iconografia coríntia dos espelhos.

É relevante apresentar o contraponto da iconografia do espelho na pintura de vasos ápulos. A análise sistemática da pintura dos vasos ápulos, mediante interpretação das séries que apontam seus variados usos (na toalete doméstica, nos rituais de iniciação amorosa, nos rituais funerários e nos cultos de adoração a Afrodite e Eros) e simbolismos (função primária de refletir a imagem no cuidado da beleza, símbolo de que moça está preparada para o casamento, atributo de Afrodite, símbolo místico de oráculo das almas, simbologia funerária dionisíaca, símbolo de ritual de iniciação amorosa) evidencia que, no fundo, uma marca singular do espelho na iconografia ápula é sua simbologia mística geral, baseada em um sistema de crença. Em primeiro plano, de crenças ligadas às expectativas amorosas, ancoradas nos auspícios de Afrodite e Eros; em segundo plano, crenças ligadas às expectativas relacionadas ao postmortem, apoiadas na associação destas divindades a Dioniso; em quarto plano, talvez por decorrência do segundo, as crenças mânticas nos poderes oraculares do espelho, por meio do qual as almas dos mortos poderiam se expressar; e, por fim, em um quarto plano, de crenças de natureza místico-religiosa, em que o espelho aparece como aparelho dos cultos dedicados a Afrodite e Eros (Vergara Cerqueira, 2018; Cassimatis 1998). 
Vê-se uma distância razoável com relação à iconografia ática, tanto dos vasos quanto dos espelhos. Se no repertório ápulo predomina o sentido místico-religioso, nos repertórios áticos o predomínio recai sobre $\mathrm{o}$ sentido amoroso, sobre o prazer erótico (Kuzmina, 2013: 158) ou sobre a proteção da vida matrimonial, mesmo que este não seja tratado de forma homogênea: no vasos, constata-se forte associação simbólica às hetairas e ao tipo de prazer sexual que se busca junto a elas; nos espelhos, predominam as representações de Afrodite e de Dioniso, alternadas com variadas abordagens mitológicas de pares amorosos. É verdade que se pode identificar, entre os espelhos coríntios e a pintura dos vasos áticos, uma vinculação comum do espelho ao prazer amoroso carnal.

Mas nem tudo é dessemelhança entre a iconografia ática e ápula. Há um ponto de convergência no sentido ritualístico do espelho, condicionado por seu possível uso em rituais dedicados a Afrodite e/ou a Eros, campo em que se aproxima de Dioniso, campo de crenças e veneração combinada, como nas Afrodísias de Corinto - isto sugere usos do objeto espelho em rituais a estas divindades, que podem incluir iniciações religiosas de sentido amoroso.

O contraste entre a iconografia da Grécia egeia e da Magna Grécia lembremos que, ao compararmos os espelhos gregos e os vasos ápulos, estamos operando na sincronia - nos apontam mais um ponto relevante a ser considerado. Estudos sobre o espelho na Grécia antiga apontam genericamente que se trata de "coisa de mulheres" (Vernant, 1989: 118), ou, mais ainda, de que seja um objeto reservado às mulheres e interdito aos homens, ao ponto de que, para um homem, olhar-se no espelho, seria vergonhoso. Enfim, objeto do "mundo das mulheres" (Frontisi-Ducroux, Vernant, 1997)33. A cerâmica ápula, contudo, em sua iconografia, apresenta situações variadas em que o espelho está colocado em relação com figuras do sexo masculino: nos rituais de iniciação amorosa, ocorre que o rapaz olhe no espelho, como parte do ritual; em contexto mortuário, considerando as crenças e práticas funerárias que incluem o espelho, ele é um objeto que precisa ser manipulado igualmente por homens e mulheres. Não há como se negar que estas situações geram certo ceticismo com relação à afirmação recorrente de que o espelho, em seu campo simbólico e pragmático, seja exclusividade feminina. Para Cassimatis (1998: 301), baseada em evidências variadas que indicam usos

33 "Dans la vie quotidienne des Anciens le miroir est par excellence chose de femmes. Il évoque le rayonnement de leur beauté, l'éclat de leur séduction, le charme de leur regard, de leurs cheveux bouclés, de leur teint délicat." 
e simbolismos masculinos do espelho ${ }^{34}$, "não se pode continuar a raciocinar conforme o critério tradicional espelho=mulher".

O repertório de pares eróticos mitológicos representados sobre espelhos merece também alguma atenção. Penso que podem contribuir para refletirmos sobre a questão levantada acima. Se os espelhos seriam de fato um objeto exclusivo do "mundo das mulheres", ligado à sedução demandada pelos homens às mulheres (Frontisi-Ducroux in FrontisiDucroux, Vernant, 1997: 100), qual seria o sentido de se representarem pares homoeróticos? Pares em que os prazeres e seduções envolvidos são masculinos. Mesmo que o espelho calcídico representando Zeus e Ganimedes (Fig. 08) possa refletir a influência da obra do escultor ateniense Leochares, há aí um olhar masculino, um olhar de um erastes que se identifica com Zeus disfarçado de águia, quando este rapta o belo efebo, levando o desejado eromenos para seu reino.

Outra dúvida: pode-se pensar uma unidade do "mundo das mulheres", não importando se hetaira ou cidadã-esposa? $O$ mundo das mulheres dignamente representadas em sua toalete (Fig. 15) e o mundo das hetairas e seus serviços sexuais se homogeneiza no espelho? Direcionando a pergunta de outro modo: as cenas de symplegma, como o espelho coríntio de Boston (Fig. 07), estariam a serviço de um olhar masculino ou feminino do prazer? As mulheres do espelho de Boston, produzido na capital grega dos prazeres da prostituição, penetradas por seus parceiros sexuais, poderiam ser "mulheres cidadãs", em seus prazeres da vida conjugal? A meu ver, bem mais provável que se trate de um homem se divertindo com uma hetaira. A historiografia, na verdade, me condiciona a pensar assim. Mas, neste caso, o espelho segue a serviço de um olhar feminino? Bem, pode ter sido um espelho de uma hetaira! Como o espelho que Laís de Corinto, a célebre cortesã, dita "a Bela", teria consagrado a Afrodite no santuário da deusa em Corinto ${ }^{35}$. Ou como tantos outros espelhos referidos nos epigramas votivos. Mas, e se o olhar

\footnotetext{
34 Além das evidências da iconografia dos vasos ápulos, Cassimatis (1998) considera, como testemunho de significados masculinos do espelho, evidências funerárias (p. 298299) e literárias (p. 300), recordando testemunhos, sobre usos masculinos do espelho, de Diógenes Laércio (II.33.9; III.39.4), com relação a conselhos dados por Aristóteles e Platão, e de Plutarco (Dem. 11.1.9), sobre Demóstenes.

35 Plat. Anth. Pal. VI.1 (Epigramas votivos): "I, Lais, whose haughty beauty made mock of Greece, I who once had a swarm of young lovers at my doors, dedicate my mirror to Aphrodite, since I wish not to look on myself as I am, and cannot look on myself as I once was".

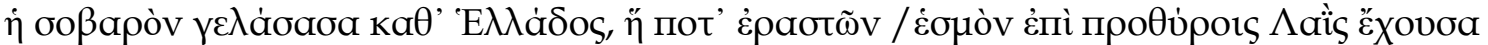

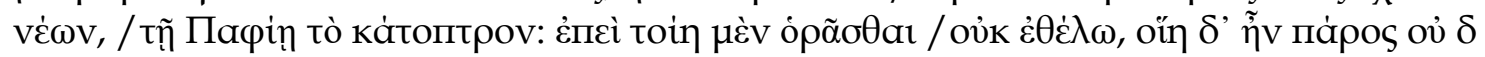
vंvapat. (Paton)
} 
for masculino, como fica a condição do espelho de uma "coisa de mulheres"?

Difíceis respostas. Deixo estas questões em aberto, como estímulo a se desenvolverem pesquisas sobre este instigante objeto e suas representações.

Mas me pergunto: passaria a resposta sobre o sentido do espelho pelo duplo caráter de Afrodite, da deusa que une? Da deusa que transpõe as barreiras sociais, deusa de todas as mulheres (hetairas, escravas, esposas, noivas), deusa de todos os amores, dos desejos descontrolados ou do amor planejado, do amor heterossexual e mesmo do desejo homoerótico. Deusa da fertilidade compartilhada com Dioniso (de Afrodite Antheia parceira de Dioniso Antheios). Deusa da mulher que casa e quer filhos, deusa da beleza sedutora das cortesãs, deusa do prazer sexual carnal. $\mathrm{O}$ sentido geral que perpassa a axiologia do espelho na Grécia parece vincular-se a uma elogio da erótica, um sentido de uma erótica que une as eróticas separadas pelas barreiras sociais, erótica em que Pandêmia e Urânia se fundem.

Eis a enorme força social deste objeto "espelho", que simboliza o poder da erótica - do prazer, do desejo, do amor - unindo o que a sociedade separa.

\section{Agradecimentos}

Agradeço, pelo financiamento da pesquisa, à Fundação Humboldt, à CAPES e ao CNPQ; pela cooperação acadêmica, ao Prof. Dr. Reinhard Stupperich (Universität Heidelberg), à arqueóloga Dra. Corinna Hoff, à Profa. Dra. Ingrid Krauskopf (Universität Heidelberg), à profa. Dra. Claude Pouzadoux (Centre Jean Bérard, Nápoles), ao Prof. Dr. Airton Pollini (Université Haute-Alsace, Mulhouse) e ao Prof. Dr. Manuel Albaladejo de Vivero (Universidad de Valencia); pelo apoio institucional, ao Instituto de Arqueologia Clássica da Universidade de Heidelberg e ao Centre Jean Bérard, Nápoles, da Escola Francesa de Roma; pela tradução e revisão, a José A. Curbelo e Priscilla Ulguim. 


\section{Textos antigos}

CICERO. De Natura Deorum. With an English translation by $\mathrm{H}$. RACKHAM. In twenty-eight volumes. Loeb Classical Library. London: William Heinem Ann Ltd., 1967.

HYGINUS. The Myths of Hyginus. (Including the Fabulae and the second book of the Poetica astronomica.) Translated and edited by MARY GRANT. Transl. By Mary Amelia Grant, Lawrence: University of Kansas Press, 1960.

PLINY THE ELDER. The Natural History. With translation of John Bostock. London: Taylor and Francis, 1855.

PLINY THE ELDER. Naturalis Historia. Karl Friedrich Theodor Mayhoff (ed.). Lipsiae: Teubner, 1906.

THE GREEK ANTHOLOGY. With an English Translation. Transl. by William Roger Paton. London: Loeb, 1916-1918.

\section{Referências bibliográficas}

BALENSIEFEN, Lilian. Die Bedeutung des Spiegelsbildes als ikonographisches Motiv in der antiken Kunst. Tübinger Studien zur Archäologie und Kunstgeschichte, Band 10, Tübingen: Ernst Wasmuth Verlag, 1990.

BRODERSEN, Kai; ZIMMERMANN, Bernhard. « Leochares », Metzler Lexikon Antike, $2^{\mathrm{a}}$ ed., Stuttgart - Weimer: Verlag J.B. Metzler, 2006, p. 335.

BURKERT, Walter. Griechische Religion. Stuttgart, Berlin, Köln, Mainz, 1977.

CASSIMATIS, Hélène. Le miroir dans les représentations funéraires apuliennes. Mélanges de l'École française de Rome. Antiquité. 110, 1, 1998, p. 297-350.

CASSIMATIS, Hélène. Le lébès à anses dressée italiote. Cahier du Centre Jean-Bérard, XV, Nápoles: Centre Jean-Bérard, École Française de Rome, 1992.

DELATTE, Armand. La catoptromancie grecque et ses dérivés. Bibliothèque de la Faculté de Philosophie et Lettres, 48. Liège: Université de Liège, 1932. 
EDWARDS, Charles. Aphrodite on a ladder. Hesperia. 53, 1, 1984, p. 59-72, pr. 17-19.

FRONTISI-DUCROUX, Françoise; VERNANT, Jean-Pierre. Dans l'æil du miroir. Paris : Éditions Odile Jacob, 1997.

GLYN-JONES, Ann. Holding up a mirror. How Civilizations decline. Bowling Green, USA \& Thorventon, UK: Imprint Academic, 1996.

HARTLAUB, Georg Friedrich. Zauber des Spiegels. Geschichte und Bedeutung des Spiegels in der Kunst. München: Piper Verlag, 1951.

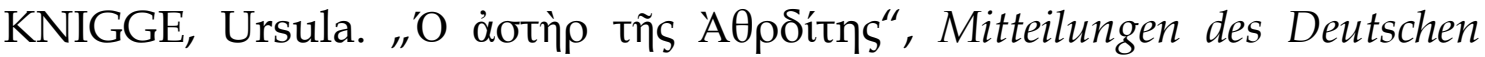
Archäologischen Instituts, Athenische Abteilung. 97, 1982, p. 153-170.

KREILINGER, Ulla. Anständige Nacktheit. Körperpflege, Reinigungsritten und das Phänomen weiblicher Nackheit im archaisch-klassischen Athen. Tübinger Archäologische Forschungen, Band 2, Rahden/Westf.: Verlag Leidorf, 2007.

KUNZE-GÖTTE, Erika. Frauengemachbilder in der Vasenmalerei des fünften Jahrhunderts. Tese de Doutorado, Arqueologia Clássica, Universidade de Munique, 1957.

KUZMINA, Eugenia. El espejo: un misterio desde cuatro contiguidades. Escrita e imagen. vol. 9, 2012, p. 155-189.

LIND, Herrmann. Ein Hetärenhaus am Heiligen Tor? Der Athener Bau Z und die bei Isaios (6, 20f.) erwähnte Synoikia Euktemons. Museum Helveticum. Revue suisse pour l'étude de l'antiquité classique. 45, 3, 1988, p. 158-179.

MAFFRE, Jean.-Jacques. A vida na Grécia clássica. Rio de Janeiro: Zahar Ed., 1989.

MELCHIOR-BONNET, Sabine. The Mirror: a History. New York, London: Routledge, 2002 (1994).

NILSSON, Martin P. Griechische Feste: von religiöser Bedeutung mit Ausschluss der Attischen. Stuttgart und Leipzig: B.G. Teubner, 1995 (1906).

RIDDER, A. de. s.v. "Speculum », Dictionnaire des Antiquités grecques et romaines. Tome quatrième, deuxième partie. Paris: Hachette, 1909, p. 1422-1430. 
MATTUSCH, Carol C. s.v. " Metalwork ", The Oxford Encyclopedia of Ancient Greece \& Rome (Michail Gagarin e Elaine Fantham, eds.). Vol. I, Oxford: University Press, 2010, p. 399-404.

ROSENZWEIG, Rachel. Worshipping Aphrodite: Art and Cult in Classical Athens. Tese de Doutorado (2003). Ann Arbour: University of Michigan Press, 2004.

SARIAN, Haiganuch. Arqueologia da Imagem: aspectos teóricos e metodológicos na iconografia de Héstia. Rev. do Museu de Arqueologia e Etnologia, São Paulo, Suplemento 3, p. 69-84, 1999.

SCHNEIDER-HERRMANN, G. Apulian red-figured paterae with flat or knobbed handles. Bulletin Supllement n. 34, London: University of London, Institute of Classical Studies, 1977.

SCHNEIDER-HERRMANN, G. Spuren eines Eroskultes in der italischen Vasenmalerei. BABesch. 45, 1970, p. 86-117.

STARR, Chester G. An evening with the flute-girls. La Parola del Passato. 1978, p. 401-10.

TREISTER, Michail Yu. The role of metals in Ancient Greek History. New York, Leiden, Köln: Brill, 1996.

VERGARA CERQUEIRA, Fábio. Espelho: imagens e significados na pintura dos vasos ápulos. In: Gil, R.; Alba, E.; Albaladejo, M.; Domènech, S. La visión especular: el espejo como tema y como símbolo. Barcelona: Editorial Calambur, 2018 (prelo).

VERGARA CERQUEIRA, Fábio. Os instrumentos musicais na vida diária da Atenas tardo-arcaica e clássica. $\mathrm{O}$ testemunho dos textos antigos e da iconografia dos vasos áticos. 3 volumes. Tese de doutorado. Antropologia Social. Faculdade de Filosofia, Letras e Ciências Humanas, Universidade de São Paulo, 2001.

VERNANT, Jean-Pierre. Au miroir de Méduse. In: Vernant, J.-P. L'individu, la mort, l'amour. Soi-même et l'autre en Grèce ancienne. Paris: Gallimard, 1989, p. 117-129.

ZÜCHNER, Wolfgang. Griechische Klappspiegel. Berlin: Walter de Gruyter, 1942. 